\title{
Health Risks to the Russian Population from Temperature Extremes at the Beginning of the XXI Century
}

\author{
Elena A. Grigorieva ${ }^{1, *(1)}$ and Boris A. Revich ${ }^{2}$ \\ 1 Institute for Complex Analysis of Regional Problems, Far Eastern Branch Russian Academy of \\ Sciences (ICARP FEB RAS), 679016 Birobidzhan, Russia \\ 2 Institute of Economic Forecasting Russian Academy of Sciences (IEF RAS), 117418 Moscow, Russia; \\ brevich@yandex.ru \\ * Correspondence: eagrigor@yandex.ru
}

Citation: Grigorieva, E.A.; Revich, B.A. Health Risks to the Russian Population from Temperature Extremes at the Beginning of the XXI Century. Atmosphere 2021, 12, 1331. https://doi.org/10.3390/ atmos12101331

Academic Editor: Graziano Coppa

Received: 31 August 2021

Accepted: 8 October 2021

Published: 12 October 2021

Publisher's Note: MDPI stays neutral with regard to jurisdictional claims in published maps and institutional affiliations.

Copyright: (c) 2021 by the authors. Licensee MDPI, Basel, Switzerland. This article is an open access article distributed under the terms and conditions of the Creative Commons Attribution (CC BY) license (https:/ / creativecommons.org/licenses/by/ $4.0 /)$.

\begin{abstract}
Climate change and climate-sensitive disasters caused by climatic hazards have a significant and increasing direct and indirect impact on human health. Due to its vast area, complex geographical environment and various climatic conditions, Russia is one of the countries that suffers significantly from frequent climate hazards. This paper provides information about temperature extremes in Russia in the beginning of the 21st century, and their impact on human health. A literature search was conducted using the electronic databases Web of Science, Science Direct, Scopus, and e-Library, focusing on peer-reviewed journal articles published in English and in Russian from 2000 to 2021. The results are summarized in 16 studies, which are divided into location-based groups, including Moscow, Saint Petersburg and other large cities located in various climatic zones: in the Arctic, in Siberia and in the southern regions, in ultra-continental and monsoon climate. Heat waves in cities with a temperate continental climate lead to a significant increase in all-cause mortality than cold waves, compared with cities in other climatic zones. At the same time, in northern cities, in contrast to the southern regions and central Siberia, the influence of cold waves is more pronounced on mortality than heat waves. To adequately protect the population from the effects of temperature waves and to carry out preventive measures, it is necessary to know specific threshold values of air temperature in each city.
\end{abstract}

Keywords: climate change; heat and cold waves; human health; Russia

\section{Introduction}

It is well documented that climatic and weather extremes - heat and cold waves, floods, droughts, etc., are associated with human-induced climate change, and reflect the growing climatic variability [1-41]. Long-term changes in the Earth's energy balance increase the frequency, intensity and duration of temperature extremes $[3,14,16,19,26-28,33,35,36,40,41]$, the probability of compound and cascading events $[1,2,6,13,16,17,20,22,24,29,35,41]$, including wildfires $[17,32,34]$. Their accelerating trends are predicted under certain scenarios of greenhouse gas emissions $[2,10,16,27,33,38,40]$. Historically, extreme weather and climate events are generally rare across the globe, with a time interval between events that allow human and natural systems to recover from the impacts experienced [30,37,39].

Significant and increasing direct and indirect impacts of extreme temperature events on human health - excessive morbidity and mortality [2,8,42-128], negative effects on mental health [8,53,124,129-136], human and community well-being [1,8,30,76,86,120,126,129,130], and health care systems $[57,125,137]$ - are becoming an increasingly urgent global problem. Much is known about health consequences of heat and cold waves [1,42-44,46$49,51,55,56,62,69-74,79,81,83,86,93-101,107-112,118,121,122]$, wildfires associated with extreme heat events and their health outcomes $[78,108]$, on a global and regional scale. Children, the elderly, and people with cardiopulmonary disease are recognized as the 
most vulnerable groups of the population to the effects of episodes with extreme temperatures $[45,53,57,62,64,73,78,81,91,104,116,121,124,127,129]$.

The variety of publications on the effects of temperature waves on the health of the population is rapidly growing, both in the northern and the southern regions [47,68,73,74,83,105,117,124,125]. Research on the relationship between human health and ambient temperature focuses mainly on the effects of extreme heat. As an example, the danger of heat extremes for public health was particularly evident in August 2003 in Western Europe, when the heat wave had caused over 70,000 additional deaths $[1,27,28,47,68,83,119]$. In 2010, a "mega heatwave" with maximum temperatures up to $40^{\circ} \mathrm{C}$ and the combined effect of heat and smoke from numerous wildfires, covered Eastern Europe, the European part of Russia and southern Siberia [47]; estimates for the death toll were 55,000 in Russia and 11,000 in Moscow, with 15 billion USD of total economic loss, which was near $1 \%$ Russian gross domestic product $[5,10,20,21,23,24,28,35,42,47,51,61,93,108,114,128,138]$. According to World Health Organization, in the European region (43 countries) in the period from 2071 to 2099, heat waves could lead to 47-117,000 additional deaths annually [77].

Nevertheless, it has been repeatedly shown that the effect of cold influence on human health, including extremely cold weather, is often stronger than heat [43,48,68,75,105-107,116,123,139-141]. In a review for southern countries, including South Korea, Thailand, Australia, Brazil, etc., significant damage to health was demonstrated due to cold, rather than heat: additional mortality during cold waves was 7.3\% (95\%, CI: 7.02-7.49\%) compared with heat waves: $0.42 \%$ (95\%, CI: 0.39-0.44\%) [68]. A study for Illinois, United States, for the period from 2011 to 2018, showed 23,834 cases of hypothermia and 24,233 cases of over-heating; 1935 deaths as a result of hypothermia and 70 of the influence of high temperatures [139]. The most vulnerable groups of the population were adults in the age cohort over 65 years of age and African-Americans - their mortality was twice as high. People who sought inpatient care for hypothermia often had much comorbidity, including electrolyte disorders, cardiovascular diseases and kidney failure [139].

The purpose of the current research is to review studies on heat and cold waves and their impact on human health in Russia at the beginning of the 21st century. In the Introduction below, we provide the definitions for heat and cold waves used worldwide and in Russia; general information about the impact of temperature extremes and temperature waves on human body; and a brief introduction to the latest events with temperature extremes in Russia. In Section 2, materials and methods are described. Section 3 provides results of the review. The combined effect of a heat wave, urban and wildfire air pollution in Russia was described in separate Section 3.7 of the Results. Section 4, Concluding Comments, includes some additional aspects: the combined effects of temperature waves and COVID-19 on human health are discussed in Section 4.1; the effects of Urban Heat Island (UHI) is considered in Section 4.2; and measures which could work for mitigating the impact of heat (cold) waves on human health in Russia are proposed and compared with those worldwide in Section 4.3. Section 5 gives the main conclusion.

\subsection{Definition of Heat and Colds Waves}

The Russian Hydrometeorological Encyclopedia defines a heat (cold) wave as a sharp increase (decrease) in temperature associated with the advection of a warm (cold) air mass [142]. Sudden departures of temperature from optimal values are understood as dangerous weather phenomena with a strong impact on various aspects of human life: energy, agriculture, water resources, etc. $[38,143,144]$. At the same time, in the world scientific literature, when studying their influence on human health, extreme temperature changes observed for several days and sometimes for a longer time, are called heat (cold) waves $[48,82,106,126,145]$.

A significant number of definitions for 'temperature wave' as a collective term that combines events with extreme temperature in(de)crease, both heat and cold waves [99,107], can be divided into absolute and relative ones $[69,71,90,102]$. In the former, fixed deviations (for example, 5 or $7^{\circ} \mathrm{C}$ ) from the threshold air temperature are examined. For example, the 
Russian Federal Hydrometeorological Service uses a very high temperature threshold to determine extremely hot weather as a dangerous phenomenon. They define a heat wave as a period with a mean daily air temperature exceeding the climatic norm for 1961-1990, by $7{ }^{\circ} \mathrm{C}$ and more, lasting five or more consecutive days [146]. In relative definitions, a wave is calculated as a certain deviation ( $\pm 2 \sigma$ or $\pm 3 \sigma$, where $\sigma$ is the standard deviation) or percentile $(1 \%, 2.5 \%, 3 \%, 5 \%$, and $95 \%, 97 \%, 97.5 \%, 99 \%$ percentile for cold and heat waves, respectively) of the temperature distribution. In contrast to absolute definitions, relative definitions allow to compare the results for different areas and averaging periods, which is especially important in a changing climate [147].

\subsection{Temperature Waves and Human Health}

Many epidemiological studies have proven the influence of long periods with extremely hot weather and heat waves on various health outcomes: daily hospital emergency transports, morbidity, general mortality and mortality from certain causes - diseases of the circulatory system, respiratory diseases, digestion, nervous system, including mental illness and suicides, etc. During heat waves, when the body is exposed to extremely high temperature, dehydration and microcirculation disorders occur, which could lead to thrombosis and chance of having strokes, exacerbations and mortality increase from ischemic heart disease and other causes. The most at-risk groups include young children, pregnant women, the elderly, people with disabilities and limited mobility, people whose professional activity is associated with outdoor activities, and people with low income $[81,85,86,91,106,117,118,120,121,125,131,134,139,148-156]$. People living in urban areas of large cities with heavy traffic, where Urban Heat Island (UHI) is developed, can also be attributed to high-risk group $[85,128,140,157,158]$. For example, high temperatures annually cause from $1 \%$ to $10 \%$ of deaths among elderly in Europe, although there is a lot of uncertainty in the calculation of years of life lost [46].

In cold exposure, the maintenance of temperature homeostasis in the human body, it's ability to keep the core temperature of the body at a normal level, is provided by compensatory and adaptive reactions of the thermoregulatory, cardiorespiratory and immune systems. Primarily, an increase in heat production and (or) a decrease in heat transfer, is manifested in a decrease of body and skin temperature and an increase in the level of basal metabolism. Adaptive shifts in the respiratory system are expressed in an increase in pulmonary ventilation. The adverse effects of cold and cold waves lead to the occurrence and (or) exacerbation of many diseases, primarily of the circulatory system and respiratory organs; children and the elderly are considered to be the most vulnerable groups of the population $[59,91,99,105,117,139,159-165]$.

\subsection{Russia and Temperature Extremes}

Due to its vast area, complex geographical and ecological environment and various climatic conditions, Russia is one of the countries that suffer the most from frequent climatic and weather extremes $[166,167]$. Climatic extremes in Russia are characterized by various types of events with high frequency, strong seasonal and regional differences and a wide range of effects $[95,168,169]$. In vulnerable regions, including the Arctic, the Far North and Siberia, extreme weather and climate events can lead to disasters with a significant impact on the health of the population, ecosystems, and various sectors of the economy [167]. For example, hot days, determined by the Federal Hydrometeorological Service as $95 \%$ extremes, were observed in 2018 in various regions [169]. An excess of up to $9{ }^{\circ} \mathrm{C}$ of the mean daily temperature in June compared to the base period of 1961-1990 was observed in a vast area between the rivers $\mathrm{Ob}$ and Lena, where a large number of settlements are located, including the large cities Novosibirsk, Krasnoyarsk, Kemerovo, Novokuznetsk, etc. The temperature anomaly in June in Central Siberia was $+4.48^{\circ} \mathrm{C}$. High summer temperatures were also observed in the Caucasus (anomalies up to $+4^{\circ} \mathrm{C}$ ) [169]. Excess elderly mortality in Russia during the hot days in summer 2018 was 18,600 cases, with similar indicators obtained in Germany $(20,200)$ and the United States $(19,000)[124]$. 
The estimation of the frequency, intensity and duration of heat waves based on the analysis of the maximum daily temperatures for June-August using the $95 \%$ percentile threshold by the middle of the 21st century compared to a 20-year period from 1980 to 1999 in Russia was considered in detail by Vinogradova [38]. An increase in the number of days with maximum temperatures exceeding the threshold values is predicted by the middle of the 21st century for some regions of Russia, including the southern parts of the European Russia and Western Siberia, Yakutia, the northern parts of Chukotkskyi Autonomous Okrug and Primorsky Krai. It is expected the maximum temperature during the heat wave will reach $40{ }^{\circ} \mathrm{C}$ [38]. In the next 30-40 years, the rate of climate change in Russia will significantly exceed the average rate of global warming [170]. In 2020 long heat wave in Siberia recorded at $+38^{\circ} \mathrm{C}$ in Verkhoyansk, the world's pole of cold, being the major Arctic event $[3,171]$, causing melting permafrost and wildfires over the vast area [172]. The extreme heat of summer 2021 has broken almost all temperature records since the beginning of the 21st century over the whole of Russia; temperatures in the Russian Arctic for several days at the end of June were above $30{ }^{\circ} \mathrm{C}$, and $15{ }^{\circ} \mathrm{C}$ higher than normal (base period 1961-1990) in some parts of Siberia [173]. Wildfires in taiga forests covered Siberia and the Far Eastern regions with smoke reaching the North Pole [174]. The consequences of these extremely hot events for human health have yet to be assessed.

On the other hand, cold is a rather serious health problem. Russia is a cold country with an average annual temperature of $-5.4{ }^{\circ} \mathrm{C}$ and mean temperature in January of $-25.2{ }^{\circ} \mathrm{C}$, ranging in different regions from +6 to $-50{ }^{\circ} \mathrm{C}$. The Siberian part of Russia is known for its extreme weather with very cold winters. The coldest place in the central part of Siberia is Oymyakon, located in the Republic of Sakha (Yakutia), where the winter temperature in January can be below $-55^{\circ} \mathrm{C}$. Prolonged exposure to extremely cold temperatures during winter can lead to death from hypothermia, which is regularly recorded in Russia [167]. A significant inter-annual variability of air temperature during the cold period was shown in Russia over the past 50 years, with increase of mean winter temperature but simultaneous decrease in the frequency of extremely cold days [175]. At the beginning of the 21st century, significant increasing trends for mean winter temperatures were noted for Saint Petersburg and Murmansk (about $0.9^{\circ} \mathrm{C} / 10$ years), for Arkhangelsk (more than $1.5^{\circ} \mathrm{C} / 10$ years) [100]. At the same time, the frequency of frosty days, defined as days with an air temperature below $95 \%$ of the percentile of the distribution of the minimum daily temperature for the period from 1970 to 2015, increased in the south of Siberia [175]. The estimation of the frequency, intensity and duration of cold waves, based on the use of the $5 \%$ percentile of the distribution of minimum daily temperatures for December-February for the 20-year period 1990-2010 compared to 1961-1990, showed that the decrease in the number of waves was followed by an increase in minimum temperatures. For the period at the beginning of the 21st century, regions with a pronounced increase in the number of long cold waves, their duration and a decrease in the minimum air temperature have been identified in the south of Siberia, the southern and central parts of the European Russia [144], which may indicate an increase in climatic extremes as an evidence of modern climate changes. For Moscow and the central regions of the European part of Russia for the period from 1976 to 2018, the decrease of temperature extremes and cold waves, expressed by the $10 \%$ percentile and $5 \%$ percentile of continuous episodes for 5 days or more, respectively, was shown [176].

\section{Materials and Methods}

A literature search was conducted using electronic databases Web of Science, Pubmed, Science Direct, Scopus, and e-Library, focusing on peer-reviewed journal articles published in English and in Russian from 2000 to 2021. Hand searching of the applicable literature was also performed in relevant journals and bibliographies of included studies. Three conceptual categories were used: "extremely hot weather", "extremely cold weather", and "human health", revealing a total of 189 records. We were seeking the key words "heat wave", "hot weather", "high temperature", and/or "cold wave", "cold spell", "cold 
weather", "extremely low temperatures", and "human health", "cardiovascular mortality", "respiratory mortality", "cardiovascular disease", "respiratory disease", "mental health", or "ambulance calls", and also looked for studies cited in the recognized articles. The papers with duplicate and overlapping results were excluded from the review and were not included into final table placed at the end of the Results section. Finally, the search identified 16 studies that were selected for the review. We did not impose any restrictions on study design.

\section{Results}

First, it was shown that heat (cold) waves were mainly defined as periods with abnormally high (low) temperatures compared to current values, often combined with high humidity (strong wind), which have an adverse effect on human body, expressed in a statistically significant increase in mortality or morbidity $[69,71,72,93-101,107-111]$. Based on long-term research, it was determined that heat (cold) waves incorporate periods with an excess of the $97(3) \%$ percentile of the distribution of mean daily temperature in the summer (winter) months $[145,177]$. This threshold value is included in the Methodological Recommendations of Russian Rospotrebnadzor [178].

In addition to the air temperature measured at a weather station, some papers examined the thermal stress expressed in terms of perceived temperature, i.e., the temperature adjusted for the complex influence of air humidity, wind, clouds and atmospheric pressure on the human body $[179,180]$. In papers $[99,110,111]$ the bioclimatic indices such as the Wind-Chill Index (WCI) [181], the Temperature-Humidity Index (HUM) [182], the Apparent Temperature (AT) by Steadman [183], the Physiologically Equivalent Temperature (PET) [184], the Universal Thermal Climate Index (UTCI) [185], are used. It was suggested that to be called a wave, the period with extreme deviations of the selected indicator should last continuously for several consecutive days; according to the duration criterion, the waves were classified as short (duration from 5 to 7 days) and long (from 8 days and longer) $[107,110]$.

When analyzing temperature waves, in addition to their duration, other indicators were described: the wave intensity, i.e. the sum of degrees above (below) the base temperature [72]; the "wave fraction" defined as the ratio of the number of days in the wave to the total number of days with temperatures above (below) the temperature threshold, for heat and cold waves, respectively [94,99]; the time shift between the beginning of the wave and the impact on the human body as the lagged effect $[55,70,97,98,100,101]$. In addition, increased (decreased) temperature background in summer (winter) [69,71,72,107] and air pollution $[73,108]$ were analyzed, which contribute to the exacerbation of diseases during heat and cold waves.

In Figure 1, the main weather stations (WS) mentioned in the studies reviewed, are shown as red dots on the map of the Russian Federation.

Table 1 provides information at these WS with World Meteorological Organization (WMO) Station Number, geographical coordinates and climate characteristics according to the Köppen-Geiger classification [186]. WS are listed here according to the WMO numbers.

The results of the review of the Russian studies on the assessment of the impact of heat and cold waves on human health were systematized geographically: mortality of the population in capital cities (Moscow, Saint Petersburg); other large cities located in various climatic zones in the Arctic (Arkhangelsk, Magadan, Murmansk, Yakutsk), in Siberia (Krasnoyarsk, Tomsk), southern (Astrakhan, Krasnodar, Rostov-on-Don, Volgograd) and Far-Eastern (Khabarovsk, Vladivostok) parts of Russia, areas with continental and monsoon climate. Other health outcomes were illustrated, such as ambulance calls during periods with heat (cold) waves. Combined effects of a heat wave, urban and wildfire air pollution in Russia were described in separate subsection of the Results. 


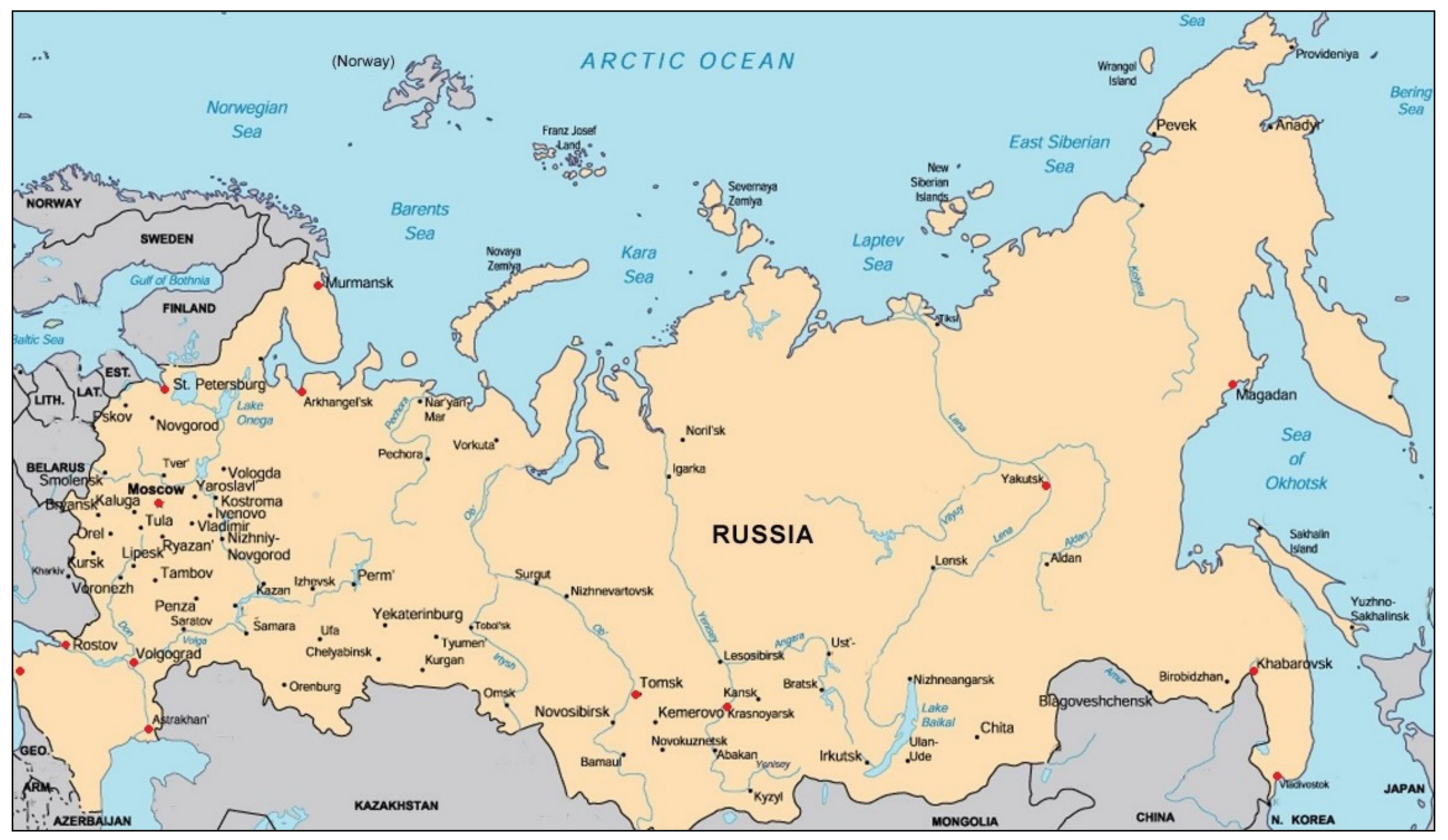

Figure 1. Map of Russia, where red dots show location of weather stations mentioned in the study.

Table 1. General information on Weather Stations mentioned in the study.

\begin{tabular}{|c|c|c|c|c|c|c|}
\hline & $\begin{array}{c}\text { Weather } \\
\text { Station Name }\end{array}$ & $\begin{array}{l}\text { WMO Station } \\
\text { Number }\end{array}$ & Latitude, ${ }^{\circ} \mathbf{N}$ & Longitude, ${ }^{\circ} \mathrm{E}$ & $\begin{array}{l}\text { Altitude, } m \text { above } \\
\text { Sea Level }\end{array}$ & $\begin{array}{c}\text { Climate Classification } \\
{[186]}\end{array}$ \\
\hline 1. & Murmansk & 22,113 & $68^{\circ} 58^{\prime}$ & $33^{\circ} 03^{\prime}$ & 57 & Dfc (Continental Subarctic) \\
\hline 2. & Arkhangelsk & 22,550 & $64^{\circ} 30^{\prime}$ & $40^{\circ} 44^{\prime}$ & 8 & Dfc (Continental Subarctic) \\
\hline 3. & Yakutsk & 24,959 & $62^{\circ} 01^{\prime}$ & $129^{\circ} 43^{\prime}$ & 98 & $\begin{array}{l}\text { Dfd (Extremely cold } \\
\text { Continental Subarctic) }\end{array}$ \\
\hline 4. & Magadan & 25,913 & $59^{\circ} 33^{\prime}$ & $150^{\circ} 47^{\prime}$ & 115 & Dfc (Continental Subarctic) \\
\hline 5. & $\begin{array}{c}\text { Saint } \\
\text { Petersburg }\end{array}$ & 26,063 & $59^{\circ} 58^{\prime}$ & $30^{\circ} 18^{\prime}$ & 3 & $\begin{array}{l}\text { Dfb (Warm Summer } \\
\text { Humid Continental) }\end{array}$ \\
\hline 6. & Moscow & 27,612 & $55^{\circ} 50^{\prime}$ & $37^{\circ} 37^{\prime}$ & 147 & $\begin{array}{l}\text { Dfb (Warm Summer } \\
\text { Continental) }\end{array}$ \\
\hline 7. & Tomsk & 29,430 & $56^{\circ} 30^{\prime}$ & $84^{\circ} 55^{\prime}$ & 141 & $\begin{array}{c}\text { Dfb (Warm Summer } \\
\text { Continental) }\end{array}$ \\
\hline 8. & Krasnoyarsk & 29,570 & $56^{\circ} 02^{\prime}$ & $92^{\circ} 45^{\prime}$ & 277 & Dfc (Continental Subarctic) \\
\hline 9. & Khabarovsk & 31,735 & $48^{\circ} 31^{\prime}$ & $135^{\circ} 10^{\prime}$ & 75 & $\begin{array}{c}\text { Dwb/Dwa } \\
\text { (Monsoon-influenced } \\
\text { warm/hot summer humid } \\
\text { Continental) }\end{array}$ \\
\hline 10. & Vladivostok & 31,960 & $43^{\circ} 48^{\prime}$ & $131^{\circ} 56^{\prime}$ & 187 & $\begin{array}{c}\text { Dwb (Monsoon-influenced } \\
\text { warm summer humid } \\
\text { Continental) }\end{array}$ \\
\hline 11. & Volgograd & 34,561 & $48^{\circ} 40^{\prime}$ & $44^{\circ} 27^{\prime}$ & 118 & $\begin{array}{l}\text { Dfa (Hot Summer } \\
\text { Continental) }\end{array}$ \\
\hline 12. & Rostov-on-Don & 34,730 & $47^{\circ} 15^{\prime}$ & $39^{\circ} 49^{\prime}$ & 88 & $\begin{array}{l}\text { Dfa (Hot Summer } \\
\text { Continental) }\end{array}$ \\
\hline 13. & Astrakhan & 34,880 & $46^{\circ} 17^{\prime}$ & $47^{\circ} 59^{\prime}$ & 22 & $\begin{array}{c}\text { BSk (Cold semi-arid } \\
\text { Steppe) }\end{array}$ \\
\hline 14. & Krasnodar & 34,929 & $45^{\circ} 03^{\prime}$ & $39^{\circ} 02^{\prime}$ & 28 & Cfa (Humid Subtropical) \\
\hline
\end{tabular}




\subsection{Moscow and Saint Petersburg}

Over the past 60 years, there has been a pronounced positive trend of air temperature in Moscow: $+0.04{ }^{\circ} \mathrm{C} /$ year for the period from 1981 to 2010 [187]. It was proposed that extremely high maximum temperatures in July, which were previously recorded once every 10 years [188], would become the norm, aggravated by a decrease of greenery and the raising of new buildings in urban areas [189].

A significant increase, by more than $5 \%$, of mortality rate in Moscow during heat waves was shown for a threshold mean daily temperature of $23.6^{\circ} \mathrm{C}$ [94,108]. During the period from 2000 to 2012, 14 heat waves were identified in Moscow [94,145]. These results were found with the exception of a strong heat wave in 2010. Since the influence of the abnormal extremely long and intensive heat wave of 2010 on health outcomes, including mortality, was too strong, the inclusion of this wave in the study sample along with "normal" heat waves largely misrepresented the results [109]. That is why the heat wave of 2010 was examined in separate papers [108,145]. In July-August 2010, the increase in mortality during the heat wave was largely due to the gradual accumulation of thermal stress as a result of many days of continuous heat exposure. The "accumulated" effect depended on the number of days in a continuous sequence of hot days, as a "wave additive" to the main heat effect $[108,145]$. Economic losses from excessive mortality as a result of exposure to prolonged heat and high level of atmospheric air pollution in the summer of 2010, was $97-123$ billion RUB, or $1.23-1.57 \%$ of Moscow's Gross Regional Product (GRP) [190].

Using the $3 \%$ percentile of mean daily temperature threshold, nine cold waves were identified in Moscow in the period from 2000 to 2012 [94]. The highest risk of additional mortality was determined for coronary heart disease and cerebrovascular diseases both in the cohort of people of working age (30-64 years), and for the elderly, as well as for respiratory diseases in the older age cohort [94], confirming the thesis about the high sensitivity of the elderly to the negative effects of low temperatures.

In Saint Petersburg over the years from 1986 to 2015, the average annual temperature has increased by $1.7^{\circ} \mathrm{C}$, and the number of days with hot weather-by $30 \%$ [191]. The average duration of heat waves for the period 1999-2016 was 9 days [100]. In the hot summer of 2010, during an intermittent heat wave, all-cause mortality increased by $30.2 \%$ compared to the summer of 2009. The relative increase in mortality per day of the 2010 heat wave was significantly higher than the increase per day in the ensemble of heat waves in other years [100].

\subsection{Arctic Macro-Region}

To identify the effect of heat waves on the mortality of the population of the Arctic macro-region, a two-stage study was conducted. At the first stage, the analysis of daily mortality and temperature indicators in four northern cities-Murmansk, Arkhangelsk, Yakutsk and Magadan —for the nine-year period 1999-2007 [107]; at the second stage-for the next 10 years until 2016 [99]. At the first stage, 29 heat waves (16 short and 13 long) were defined, and the relative risk of mortality was estimated as the ratio of the observed mortality during the wave period to the expected value for these calendar dates. It was shown that short heat waves in northern cities had a stronger impact on mortality than long heat waves with the "harvesting effect" as a possible explanation. During long-term heat waves, excess mortality at the end of a long period with excessively hot temperatures was compensated by the "harvesting effect" - a short-term shift in mortality at the beginning of the wave $[60,67,98,106,119]$. The relative risk of mortality from cerebrovascular diseases, mainly strokes, was higher than from heart attacks, but the difference between these diseases was statistically insignificant. The increase in all-cause mortality was slightly less than the increase in mortality from heart attacks and strokes, and the relative risk of mortality from external causes was statistically significant only for the age group of 30-64 years [107]. 
At the second stage of the work [99], it was shown that the air temperature was more closely related to mortality rates than the Apparent Temperature by Steadman [183]. An additional characteristic of the local climate was a "wave fraction" calculated as the ratio of the number of days included in the ensembles of waves lasting from 5 days to the total number of days with temperatures above the threshold. Since the temperature thresholds were based on percentiles, 197 days ( $3 \%$ of all days) over 18 years were attributed to heat waves. However, not all of them were included in the ensembles of temperature waves since only continuous waves lasting from 5 days were taken into account [99].

In study by B. Revich with coauthors [99] for the period 1999-2016, the cold waves in the northern cities were identified by threshold value below the $3 \%$ percentile of the mean daily air temperature and the Wind-Chill Index. The wave fraction ranged from 45 to $70 \%$ for Murmansk and Yakutsk, respectively, demonstrating the increasing effect of climate continentality. As in previous studies for other regions of Russia, cold waves have a stronger impact on the mortality of the elderly with diseases of the circulatory system. An increase in blood pressure in patients with arterial hypertension during winter compared to summer, as well as instability of heat transfer mechanisms in the elderly, could be the possible explanation $[156,160]$. In addition, chronic infectious diseases worsen in winter, increasing respiratory infections, which also leads to a growth in the number of pathologies of the circulatory system [113]. At the same time, the impact on mortality in the group of external causes was noted for the age cohort of 30-64 years, which could be explained by the extremely cold conditions for outdoor workers and high injury risk $[139,164]$.

Additional wind effect expressed by Wind-Chill Index [181] did not always give an increase in exposure: in Murmansk, statistically significant results were higher for the relationship between mortality and the Wind-Chill Index, and in Yakutsk-for the mean daily temperature [99]. Most likely, this could be explained by the fact that in the maritime climate of Murmansk, the severity of the weather increased with a strong wind, and in the ultra-continental climate of Yakutsk-with frosty, but mostly calm conditions [100].

A separate study for Arkhangelsk used several predictors as the threshold temperatures, including UTCI which accumulated the effect of air temperature and humidity, wind, atmospheric pressure and cloudiness [185]. There was a statistically significant increase in mortality rate during both heat and cold waves, depending on gender: when identifying the wave using the mean daily air temperature for women and the minimum daily UTCI for men [111]. Most likely, the contrasts can be explained by the different character of the physical and social activities of men and women [100].

\subsection{Southern Cities of the European Russia}

The southern cities of the European part of Russia are Astrakhan, Volgograd, Krasnodar, Rostov-on-Don, with population more than 3.5 million people. The frequency of heat waves here increased in 2000-2010 compared to the previous decade; extremely hot days were identified as those with temperature exceeding $\mu+2 \sigma$, where $\mu$ and $\sigma$ were arithmetic mean and standard deviation of the distribution of mean daily temperature for all days for the period from 1961 to 2010 [97]. The threshold for definition of a heat wave in July was $+29.0^{\circ} \mathrm{C}$ in Volgograd, $+28.6{ }^{\circ} \mathrm{C}$ in Astrakhan, $+28.2{ }^{\circ} \mathrm{C}$ in Krasnodar and $+27.7^{\circ} \mathrm{C}$ in Rostov-on-Don. Significant $(p<0.05)$ positive trends in mean annual temperature and temperature of July were shown for all weather stations in Astrakhan, Volgograd, Krasnodar and Rostov-on-Don. The average annual trend of the mean temperature in July for $1961-2010$ ranged from $0.02{ }^{\circ} \mathrm{C} /$ year $(p<0.01)$ to $0.09{ }^{\circ} \mathrm{C} /$ year $(p<0.001)$ in various cities, demonstrating an increase in summer temperature everywhere. The number of extremely hot days in each of the studied cities varied from 10 to 37 per year. In comparison with 1961-1990, in the next 10 years the number of extremely hot days in Volgograd increased by three times, in Krasnodar-by one and a half times; in Rostov-on-Don the increase was not significant.

In these cities, the impact of 22 short (lasting 5-7 days) and 19 long (lasting 8 days or more) heat waves on the mortality was estimated. The strongest heat wave of 2010, 
manifested in all cities, was excluded from the study. Additional mortality per 100 thousand people during heat waves was: 7.6\% (95\% CI: 6.7-8.5) in Volgograd, 8.1\% (95\% CI: 7.2-8.9) in Rostov-on-Don, 8.5\% (95\% CI: 7.5-9.6) in Krasnodar and 10.8\% (95\% CI: 9.3-12.2) in Astrakhan. The highest risk in Astrakhan was explained by the record number of long heat waves. A meta-analysis of risk in four southern cities showed statistically significant results of a combined risk assessment for 15 mortality indicators. The largest number of additional deaths was detected in Volgograd and in Rostov-on-Don during days when the temperature exceeded the specified heat threshold [97].

Additionally for mortality in Rostov-on-Don during the period from 1999 to 2011, excluding the heat wave of 2010, increase in mortality from coronary heart disease cerebrovascular diseases was shown, using air temperature (T), AT, HUM and PET as weather parameters [110]. Similar to the study in Moscow, an abnormal wave of 21 days duration in Rostov-on-Don in summer of 2010 was excluded from the sample. The study demonstrated that $\mathrm{T}$ and PET were the best predictors for mortality from coronary heart disease at the age of 30-64 years ( $R R=1.19$ (95\% CI: 0.09-2.21); PET - for mortality from cerebrovascular diseases at the age of 30-64 years (1.64 (95\% CI: 0.18-4.43) with a 2 day lag; PET-for elderly with coronary heart disease (1.51 (95\% CI: 0.09-7.03) with a 3 day lag, and with cerebrovascular diseases (1.72 (95\% CI: 0.05-18.63) with a 1 day lag [110].

A comparison of the results of assessing excess mortality during heat waves in southern in European Russia and northern cities in the Arctic region showed more significant effect of hot extremes in southern cities. The relative increase in mortality from cerebrovascular diseases at the age of $65+$ during heat waves was $66 \%$ (95\% CI: 54-78) in southern cities compared to $35 \%$ (95\% CI: 13-57) in northern cities, i.e., the relative increase in the south was almost twice as high as in the north [97]. The possible explanation could be the differences in demographical structure of the population in these regions: by the age 65 , people with potentially serious health problems change their permanent place of residence, migrating from north to south, thereby increasing the risk of mortality in southern cities [192].

\subsection{Siberia, Continental Climate}

The temperature thresholds for hot extremes in two cities of the Western Siberia (Barnaul and Kemerovo) and in four cities of the Eastern Siberia (Bratsk, Chita, Krasnoyarsk, Irkutsk) for the study period from 1999 to 2015 were homogeneous, varying in a narrow range from 21 to $23^{\circ} \mathrm{C}$ [98]. The longest heat wave (20 days) occurred in the summer of 1999 in Bratsk. The mortality risk during heat waves was calculated for Krasnoyarsk, the largest of the six Siberian cities, where the heat threshold by air temperature was $23.3^{\circ} \mathrm{C}$, and by Apparent Temperature $-22.4^{\circ} \mathrm{C}$. The maximum of the mean daily Apparent Temperature was $29.7^{\circ} \mathrm{C}$.

In Krasnoyarsk, for the period from 1999 to 2015, only 10 waves with a duration of 5 or more days, defined by Apparent Temperature, were recorded, with a total duration of 91 days [98]. Excess mortality during heat waves in the age group of elderly $(\geq 65)$ was $22 \%$ (95\% CI: 17-28), mainly due to diseases of the circulatory system (hypertension, coronary heart disease). A comparison of mortality in Krasnoyarsk with similar indicator in Rostov-on-Don in the south shows a significant difference in the mortality rate. Two times more men aged 30-64 years died from respiratory diseases in Krasnoyarsk than in the southern group; six times more-at the age of $\geq 65$ years old; and among women, two and nine times more, respectively. We would suppose the reason was the long-term exposure to polluted atmosphere in Krasnoyarsk. Additionally in Krasnoyarsk, Siberian city with an ultra-continental climate, the influence of day-to-day changes in air temperature on mortality was estimated: no correlation was shown for the age group of 30-64 years, and significant correlation for four causes (coronary heart disease, strokes, other diseases of the circulatory system and all natural causes) for elderly [98].

In Tomsk, the influence of air temperature on acute myocardial infarction (AMI) was demonstrated for 25 years from 1990 to 2015 [67]. Increase in total mortality among 
patients with AMI and in percentage of women and elderly in structure of AMI patients during the heat wave of 2012 compared to summer 2010, was illustrated. During the heat wave, the condition of these patients was characterized by cerebral disorders, instability of blood pressure, and a statistically significant higher proportion of hospital mortality [67]. Additionally, it was demonstrated that adverse trends in morbidity and mortality from AMI could be registered already a few days before the period of heat wave as a result of sharp changes in air temperature and a high daily gradient of atmospheric pressure [67].

In Krasnoyarsk for the years from 1999 to 2015 the cold waves were defined by the Wind-Chill index [98]. Increase in mortality during cold waves was 7.3\% (95\% CI: 1.1-13.8) for the elderly and 6.3\% (95\% CI: 1.7-11.2) for the cohort of 30-64 years, which was significantly less than for heat waves [98]. Elderly people with diseases of the circulatory system were at higher risk [98]. The lagged effect was 2-3 days, which was consistent with other research $[52,140]$. The strongest influence was found for short waves compared to long ones, which could be explained by the "harvesting effect" $[98,106]$.

In Krasnoyarsk in ten years from 2000 to 2004 and from 2010 to 2014, 59 heat waves and 60 cold waves were identified [55]. The relative risk of mortality from diseases of the circulatory system was higher than from other causes of death for both cold and heat extremes. The greatest negative impact of temperature waves was found on mortality from diseases of the circulatory system in the age group of 65 years and older with an absolute risk value, as probability of death from heat waves, at the level of $4.41 * 10^{-3}$, and from cold waves of $4.81 * 10^{-3}$. A comparison of time lags for different causes of death showed that cold waves had the most delayed effect on diseases of the circulatory system. On the contrary, the effect of heat was more rapid compared to all other causes [55].

\subsection{Cities with Monsoon Climate at the Russian Far East: Vladivostok and Khabarovsk}

The heat waves in Vladivostok were studied for the period from 2000 to 2015 [94]. The temperature threshold for heat waves was $21.9{ }^{\circ} \mathrm{C}$ for air temperature, and $22.2^{\circ} \mathrm{C}$ for Apparent Temperature [94]. Using air temperature, 11 heat waves were registered in Vladivostok during 16-year period from 2000 to 2015, with an average wave length of 10 days. Based on Apparent Temperature as indicator of exposure to heat, seven heat waves were identified, with an average wave length of 9 days. The highest statistically significant risk in absolute terms with an increase in mortality by $+37 \%$ during heat waves defined by Apparent Temperature was established for diseases of the circulatory system among the elderly [94].

For the continental monsoon climate of Khabarovsk, the period from 2000 to 2015, heat waves lasting 3 days or more with mean daily temperature above the $95 \%$ percentile of mean daily temperatures in the warm season, increased all-cause mortality by $36 \%$ with one day lag [70]. In general, the frequency of heat waves in the southern part of the Russian Far East has been constantly increasing since the 1950s, with their maximum number and intensity at the continental stations. In summer, the wave fraction as a portion of days with a wave during all days with extreme temperatures was near 35\% [72]. The hottest summer for the period from 2000 to 2017 was in 2008, when there were two waves in June, four in July and one in August [72]. In July 2011, a strong heat wave was caused by the stationing of a sedentary anticyclone in the south of the Russian Far East [11], which lasted up to 25 days and covered a vast area in the north and central part of Khabarovsky Krai [70,72].

It the continental part of the southern Far East, cold waves were defined by a threshold of $3 \%$ percentile of the distribution of mean daily temperature for the period from 1999 to 2017 and a duration of 3 days; no pronounced trend in their number was found. The winter of 2012-2013 was the most severe, with the maximum number and cumulative effect of cold waves [72]. In Khabarovsk, the winter of 2010-2011 was the coldest: four cold waves were registered; one of them in January lasted continuously for 12 days. As it was found for the continental climate of Siberia [98], the health impact of cold waves was shown to be less than of heat waves. Nevertheless, mortality in all ages and in the older age cohort, primarily cardiovascular disease, was much higher in the cold period of the year, especially 
in January, which confirmed the negative impact of the harsh cold environment of the Russian Far East on the thermoregulatory system of the human body [72].

In Vladivostok for the period from 2000 to 2016, statistically significant increases in mortality from diseases of the cardiovascular system in the cohort of the working-age population, and without significant results for the elderly, were shown during the cold waves [94]. In contrast to the continental part of the south of the Russian Far East, the stronger influence of cold waves than heat waves in Vladivostok could be explained by higher extremity of winter weather in the marine climate and higher wave fraction in Vladivostok (64\% for cold waves and 57\% for heat waves) [94] compared to Khabarovsk ( $40 \%$ for cold waves and $36 \%$ for heat waves) [72].

\subsection{Ambulance Calls during Periods with Extreme Air Temperature}

Along with excessive mortality during heat waves, the number of emergency medical calls and the number of hospitalizations with various health disorders are also increasing. This is proved by studies in Moscow during the heat wave of 2010, where increase in ambulance calls was demonstrated for stroke, hypotension, angina-up to 2.5 times, for pneumonia - up to five times, compared to the same period of 2009 [54]. In Simferopol, the frequency of emergency calls in July was associated with high temperatures and increased concentrations of ozone in the air [65]. Increase in cardiovascular exacerbations in some patients with cardiovascular diseases-hypertensive crisis for hospital patients and ambulance calls was shown for cold wave in Moscow in winter 2012-2013 [43].

\subsection{Combined Effects of a Heat Wave, Urban and Wildfire Air Pollution}

The main region burned by wildfires in Russia is located in the Siberian taiga; global warming is projected to increase frequency and area covered by fires, reaching the northern Arctic seas [17]. For example, in Khakassia, southern Siberia, grass fires in 2015 covered a vast area, destroyed 1140 houses; the fires and smoke affected 1500 people, causing serious health problems with 27 fatalities.

During the extraordinary events of the summer of 2010, fires and smoke spread across 17 regions of Russia, leading to heavy smoke in large cities and a significant increase in deaths. This catastrophic wildfire has particularly highlighted the problem of the combined impact of high temperature and increased air pollution on human health $[5,61,96,108,193]$. High surface concentrations of $\mathrm{CO}, \mathrm{PM}_{10}$ and ozone [194] were detected; on several days $\mathrm{PM}_{10}$ levels exceeded $300 \mu \mathrm{g} / \mathrm{m}^{3}$ [108]. More than 3,000,000 hectares of forest was burned by 500 wildfires; 806 people sought for medical help, and according to different sources, the death toll from the fires was 53 to $60[17,193]$. The combined impact of high temperature and increased air pollution on the mortality of the Moscow population in 2007-2014 was shown by cardiologists, with relative risk of heat wave exposure $R R=1.46$ for all-cause mortality and 1.65 for mortality from diseases of the circulatory system (Table 2), i.e., mortality increases by about one and a half [49].

Table 2. Characteristics of studies included in the review.

\begin{tabular}{|c|c|c|c|c|c|}
\hline Study & Study Area & Study Period & $\begin{array}{c}\text { Threshold } \\
\text { Temperature }^{1}\end{array}$ & Hot Weather Description ${ }^{2}$ & Results $^{3}$ \\
\hline \multicolumn{6}{|c|}{ Heat waves } \\
\hline Boytsov et al. [49] & Moscow & 2007-2014 & Daily $\mathrm{T}, \mathrm{T}_{\max }$ & $\begin{array}{c}\text { HW: } \mathrm{T}_{\max } \geq 28^{\circ} \mathrm{C} \text {, duration } \\
4 \text { days and more }\end{array}$ & $\begin{array}{l}\text { Increase in all-cause mortality: } \\
\mathrm{RR}=1.43 \%(95 \% \text { CI: } 1.41-1.45) \\
\text { CVD }=1.65 \%(95 \% \text { CI: } 1.62-1.67)\end{array}$ \\
\hline $\begin{array}{l}\text { Chereshnev et al. } \\
\text { [54] }\end{array}$ & Moscow & 2006-2011 & Daily T & HW in 2010 & $\begin{array}{l}\text { Increase in ambulance calls during } \\
\text { HW in } 2010 \text { compared to summer } \\
\text { 2009: for stroke, hypotension, } \\
\text { angina-up to } 2.5 \text { times, for } \\
\text { pneumonia-up to } 5 \text { times }\end{array}$ \\
\hline $\begin{array}{c}\text { Chernykh, Taseiko } \\
{[55]}\end{array}$ & Krasnoyarsk & $\begin{array}{l}2000-2004 \\
2010-2014\end{array}$ & Daily T & $\begin{array}{l}\text { HW: } \mathrm{T}>97 \text { th percentile of } \\
\text { the year-round distribution } \\
\text { during the study period, } \\
\text { duration }>5 \text { days }\end{array}$ & $\begin{array}{l}\text { Absolute risk of increase mortality: } \\
\text { CVD (elderly) }=4.4^{*} 10^{-3} ; \mathrm{RD} \\
(30-64 \text { year old })=3.1^{*} 10^{-4} ; \mathrm{ED} \\
(30-64)=1.63^{*} 10^{-3}\end{array}$ \\
\hline
\end{tabular}


Table 2. Cont.

\begin{tabular}{|c|c|c|c|c|c|}
\hline Study & Study Area & Study Period & $\begin{array}{c}\text { Threshold } \\
\text { Temperature }^{1}\end{array}$ & Hot Weather Description ${ }^{2}$ & Results $^{3}$ \\
\hline $\begin{array}{c}\text { Garganeeva et al. } \\
{[67]}\end{array}$ & Tomsk & $\begin{array}{l}\text { Summer of } 2010 \\
\text { and } 2012\end{array}$ & Daily T & $\begin{array}{c}\mathrm{HW}: \mathrm{T} \geq \mu+1.25 \sigma \\
\text { (reference period } 1990-2015 \text { ), } \\
\text { duration } 5 \text { days and more }\end{array}$ & $\begin{array}{l}\text { Increase in total mortality among } \\
\text { patients with AMI; increase in } \\
\text { percentage of women and elderly in } \\
\text { structure of AMI patients during the } \\
\text { heat wave of } 2012 \text { compared to } \\
\text { summer } 2010\end{array}$ \\
\hline Grigorieva [70] & Khabarovsk & 2000-2015 & Daily T & $\begin{array}{l}\text { HW: } \mathrm{T}>95 \text { th percentile of } \\
\text { the year-round distribution } \\
\text { during the study period, } \\
\text { duration }>3 \text { days }\end{array}$ & $\begin{array}{c}\text { Increase in all-cause mortality by } 36 \% \\
\text { with one day lag }\end{array}$ \\
\hline Revich [94] & Moscow & 2000-2012 & Daily T & $\begin{array}{l}\text { HW: } \mathrm{T}>97 \text { th percentile of } \\
\text { the year-round distribution } \\
\text { during the study period, } \\
\text { duration }>5 \text { days }\end{array}$ & $\begin{array}{c}\text { 30-64 years old: CVD RR = } 1.20 \text { (95\% } \\
\text { CI: } 1.13-1.27), \text { ED }=1.13 \% \text { (95\% CI: } \\
1.09-1.19), \text { NA }=1.02 \% \text { ( } 95 \% \text { CI: } \\
1.00-1.04) ; \geq 65 \text { years old: IHD = } 1.12 \\
\text { (95\% CI: } 1.10-1.14), \text { CVD }=1.28 \text { (95\% } \\
\text { CI: } 1.24-1.31), \text { RD }=1.19(95 \% \text { CI: } \\
1.09-1.31), \text { NA }=1.15 \%(95 \% \text { CI: } \\
1.13-1.16)\end{array}$ \\
\hline Revich [94] & Vladivostok & 2000-2015 & Daily T, AT & $\begin{array}{l}\text { HW: } \mathrm{T}>97 \text { th percentile of } \\
\text { the year-round distribution } \\
\text { during the study period, } \\
\text { duration }>5 \text { days }\end{array}$ & $\begin{array}{c}\text { IHD (30-64 years old) RR }=1.17 \% \\
\text { (95\% CI: } 1.00-1.37), \text { RD } \\
(30-64)=1.57 \%(95 \% \text { CI: } 1.18-2.08) \\
\text { ED }(30-64)=1.22 \%(95 \% \text { CI: } \\
1.02-1.47), \text { NA }(\geq 65)=1.08 \%(95 \% \text { CI: } \\
1.01-1.16)\end{array}$ \\
\hline Revich et all. [97] & $\begin{array}{l}\text { Astrakhan, } \\
\text { Volgograd, } \\
\text { Krasnodar, } \\
\text { Rostov-on-Don }\end{array}$ & 2000-2010 & Daily T & $\begin{array}{l}\mathrm{HW}: \mathrm{T}>\mu+2 \sigma \text { (reference } \\
\text { period 1961-2010), } \\
\text { duration }>5 \text { days }\end{array}$ & $\begin{array}{c}\text { Increase in all-cause mortality: } \\
\text { Astrakhan RR }=10.8 \%(95 \% \text { CI: } \\
\text { 9.3-12.2); Krasnodar }=8.5 \%(95 \% \text { CI: } \\
\text { 7.5-9.6); Rostov-on-Don }=8.1 \%(95 \% \\
\text { CI: 7.2-8.9); Volgograd }=7.6 \%(95 \% \text { CI: } \\
\text { 6.7-8.5) }\end{array}$ \\
\hline $\begin{array}{l}\text { Revich, } \\
\text { Shaposhnikov [98] }\end{array}$ & Krasnoyarsk & 1999-2015 & Daily T, AT & $\begin{array}{l}\text { HW: } \mathrm{T}>97 \text { th percentile of } \\
\text { the year-round distribution } \\
\text { during the study period, } \\
\text { duration }>5 \text { days }\end{array}$ & $\begin{array}{c}\text { Increase in NA (30-64 year old) } \\
\mathrm{RR}=1.095,(\text { elderly })=1.22 \\
\text { hypertension (elderly) }=1.84, \text { strokes } \\
\text { (elderly) }=1.44\end{array}$ \\
\hline Revich et al. [99] & $\begin{array}{l}\text { Northern cities } \\
\text { Arkhangelsk, } \\
\text { Murmansk, } \\
\text { Yakutsk }\end{array}$ & 1999-2016 & Daily T, AT & $\begin{array}{l}\text { HW: } \mathrm{T}(\mathrm{AT})>97 \text { th percentile } \\
\text { of the year-round } \\
\text { distribution during the study } \\
\text { period, duration }>5 \text { days }\end{array}$ & 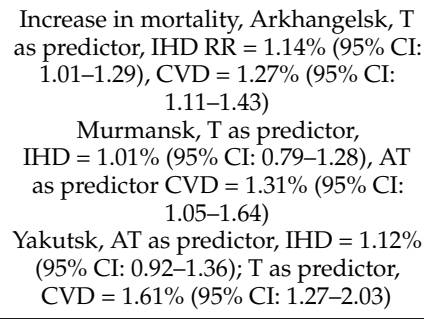 \\
\hline Revich et al. [100] & St-Petersburg & 1999-2016 & Daily T, AT & $\begin{array}{l}\text { HW: } \mathrm{T}(\mathrm{AT})>97 \text { th percentile } \\
\text { of the year-round } \\
\text { distribution during period } \\
\text { from } 1961 \text { to } 2017 \\
\text { duration }>5 \text { days }\end{array}$ & $\begin{array}{c}\mathrm{T} \text { as predictor: } \mathrm{RD}(\geq 65) \mathrm{RR}=1.19 \% \\
(95 \% \mathrm{CI}: 1.01-1.40)\end{array}$ \\
\hline Revich et al. [100] & St-Petersburg & Summer 2010 & Daily T, AT & $\begin{array}{l}\text { HW: } \mathrm{T}(\mathrm{AT})>97 \text { th percentile } \\
\text { of the year-round } \\
\text { distribution for the period } \\
\text { from } 1961 \text { to } 2017 ; \\
\text { duration }>5 \text { days }\end{array}$ & $\begin{array}{c}\text { AT as predictor: RD }(\geq 65 \text { years old }) \\
\text { RR }=1.34 \% \text { ( } 95 \% \text { CI: } 1.08-1.68) ; \mathrm{NA} \\
(\geq 65)=1.26 \%(95 \% \text { CI: } 1.22-1.30) \\
\text { Increase in all-cause mortality in } 2010 \\
\text { by } 30.2 \% \text { compared to the summer } \\
\text { of } 2009\end{array}$ \\
\hline $\begin{array}{l}\text { Shaposhnikov, } \\
\text { Revich [107] }\end{array}$ & $\begin{array}{l}\text { Northern cities } \\
\text { Arkhangelsk, } \\
\text { Magadan, } \\
\text { Murmansk, } \\
\text { Yakutsk }\end{array}$ & 1999-2007 & Daily T & $\begin{array}{l}\text { HW: } \mathrm{T}>97 \text { th percentile of } \\
\text { the year-round distribution } \\
\text { during the study period, } \\
\text { duration }>5 \text { days }\end{array}$ & $\begin{array}{c}\text { Arkhangelsk }(30-64 \text { years old) } \\
\text { RR }=1.02,(\text { elderly })=1.13 \\
\text { Magadan }(30-64)=1.32, \\
\text { (elderly) }=1.12 \\
\text { Murmansk }(30-64)=1.05, \\
\text { (elderly) }=1.01 \\
\text { Yakutsk }(30-64)=1.04,(\text { elderly })=1.03\end{array}$ \\
\hline $\begin{array}{l}\text { Shaposhnikov et al. } \\
\text { [108] }\end{array}$ & Moscow & $\begin{array}{l}\text { 6 June- } \\
18 \text { August } 2010\end{array}$ & Daily T, AT & $\begin{array}{l}\text { HW: } \mathrm{T}>97 \text { th percentile of } \\
\text { the year-round distribution } \\
\text { for the period from } 1980 \text { to } \\
2010 \text {, duration }>5 \text { days }\end{array}$ & $\begin{array}{c}\text { Added deaths due to interaction } \\
\text { between HW and air pollution, } \\
\text { elevated risks for NA (elderly) } \\
\text { RR = 2.14\% (95\% CI: } 2.06-2.23) ; \\
\text { nervous system }=3.07 \%(95 \% \text { CI: } \\
\text { 2.52-3.92), genitourinary = } 2.54 \% \text { (95\% } \\
\text { CI: } 2.14-3.12), \text { CVD }=2.37 \%(95 \% \text { CI: } \\
2.24-2.52), \text { IHD }=2.29 \text { (95\% CI: } \\
2.18-2.40), \text { RD }=2.05 \%(95 \% \text { CI: } \\
1.80-2.39)\end{array}$ \\
\hline
\end{tabular}


Table 2. Cont.

\begin{tabular}{|c|c|c|c|c|c|}
\hline Study & Study Area & Study Period & $\begin{array}{c}\text { Threshold } \\
\text { Temperature }^{1}\end{array}$ & Hot Weather Description ${ }^{2}$ & Results $^{3}$ \\
\hline Shartova et al. [110] & Rostov-on-Don & $\begin{array}{c}1999-2011 \\
\text { (excluding 2010) }\end{array}$ & $\begin{array}{l}\text { Daily T, HUM, AT, } \\
\text { PET }\end{array}$ & $\begin{array}{l}\text { HW: T (HUM, AT, } \\
\text { PET) }>\text { 97th percentile of the } \\
\text { year-round distribution } \\
\text { during the study period, } \\
\text { duration }>5 \text { days }\end{array}$ & $\begin{array}{l}\mathrm{T} \text { as predictor for the mortality from } \\
\text { CHD (30-64 years old) RR }=1.19 \% \\
\text { (95\% CI: } 0.09-2.21) \text {; PET for mortality } \\
\text { from CVD ( } 30-64)=1.64 \% \text { ( } 95 \% \text { CI: } \\
0.18-4.43), 2 \text { day lag; PET as predictor } \\
\text { (elderly): CHD }=1.51 \%(95 \% \text { CI: } \\
0.09-7.03) 3 \text { day lag, CVD }=1.72 \% \\
\text { (95\% CI: } 0.05-18.63), 1 \text { day lag }\end{array}$ \\
\hline Shartova et al [111] & Arkhangelsk & 1999-2016 & Daily T, UTCI & $\begin{array}{l}\text { HW: T }(\mathrm{UTCI})>97 \text { th } \\
\text { percentile of the year-round } \\
\text { distribution during the study } \\
\text { period, duration }>5 \text { days }\end{array}$ & $\begin{array}{c}\text { Increase in mortality using: maximum } \\
\text { daily T for women all-cause } \\
(30-64)=1.80 \text {; RD (elderly) = 0.66; } \\
\text { maximum UTCI for men with CVD } \\
(30-64)=0.67, \text { (elderly) }=2.83\end{array}$ \\
\hline $\begin{array}{l}\text { Smirnova et al. } \\
{[115]}\end{array}$ & Moscow & Summer 2010 & Daily T & HW & $\begin{array}{l}\text { Increase in hypertensive crises, } \\
\text { unscheduled visits to the doctor, } \\
\text { cardiac arrhythmias }\end{array}$ \\
\hline \multicolumn{6}{|c|}{ Cold Waves } \\
\hline Ageev [43] & Moscow & 2012-2013 & Daily T & $\begin{array}{l}\text { CW: } \mathrm{T}<3 \text { rd percentile of the } \\
\text { year-round distribution } \\
\text { during the study period, } \\
\text { duration }>5 \text { days }\end{array}$ & $\begin{array}{l}\text { Increase in cardiovascular } \\
\text { exacerbations in some patients with } \\
\text { CVD: hypertensive crisis, } \\
\text { ambulance calls }\end{array}$ \\
\hline $\begin{array}{c}\text { Chernykh, Taseiko } \\
{[55]}\end{array}$ & Krasnoyarsk & $\begin{array}{l}2000-2004 \\
2010-2014\end{array}$ & Daily T & $\begin{array}{l}\mathrm{CW}: \mathrm{T}<3 \text { rd percentile of the } \\
\text { year-round distribution } \\
\text { during the study period, } \\
\text { duration }>5 \text { days }\end{array}$ & $\begin{array}{l}\text { Absolute risk of mortality increase: } \\
\text { for CVD (elderly) }=4.81^{*} 10^{-3} ; \mathrm{ED} \\
\quad(30-64 \text { years old })=1.45^{*} 10^{-3}\end{array}$ \\
\hline Revich [94] & Moscow & 2000-2012 & Daily T & $\begin{array}{l}\mathrm{CW}: \mathrm{T}<3 \text { rd percentile of the } \\
\text { year-round distribution } \\
\text { during the study period, } \\
\text { duration }>5 \text { days }\end{array}$ & $\begin{array}{c}\geq 65 \text { years old: } \mathrm{IHD}=1.05(95 \% \mathrm{CI}: \\
1.03-1.07), \mathrm{CVD}=1.08(95 \% \mathrm{CI}: \\
1.05-1.10), \mathrm{NA}=1.05 \%(95 \% \mathrm{CI}: \\
1.04-1.06)\end{array}$ \\
\hline Revich [94] & Vladivostok & 2000-2016 & Daily T & $\begin{array}{l}\mathrm{CW}: \mathrm{T}(\mathrm{WCI})<3 \text { rd } \\
\text { percentile of the year-round } \\
\text { distribution during the study } \\
\text { period, duration }>5 \text { days }\end{array}$ & $\begin{array}{c}\text { IHD (30-64 years old) RR = } 1.30 \% \\
\text { (95\% CI: } 1.12-1.51), \mathrm{RD} \\
\text { (30-64) }=1.39 \%(95 \% \text { CI: } 1.03-1.87) \\
\text { ED }(30-64)=1.27 \%(95 \% \text { CI: } \\
1.04-1.54) \\
\text { No significant results for the elderly }\end{array}$ \\
\hline $\begin{array}{c}\text { Revich, } \\
\text { Shaposhnikov [98] }\end{array}$ & Krasnoyarsk & 1999-2015 & Daily T, WCI & $\begin{array}{l}\mathrm{CW}: \mathrm{T}(\mathrm{WCI})<3 \mathrm{rd} \\
\text { percentile of the year-round } \\
\text { distribution during the study } \\
\text { period, duration }>5 \text { days }\end{array}$ & $\begin{array}{c}\text { Increase in all-cause mortality } \\
\text { (30-64 years old) RR }=7.3 \% \text { ( } 95 \% \text {, CI: } \\
1.1-13.8) \text {, (elderly) }=6.3 \%(95 \%, \mathrm{CI}: \\
1.7-11.2)\end{array}$ \\
\hline Revich et al. [99] & $\begin{array}{l}\text { Northern cities } \\
\text { Arkhangelsk, } \\
\text { Murmansk, } \\
\text { Yakutsk }\end{array}$ & 1999-2016 & Daily T, WCI & $\begin{array}{l}\mathrm{CW}: \mathrm{T}(\mathrm{WCI})<3 \text { rd } \\
\text { percentile of the year-round } \\
\text { distribution during the study } \\
\text { period, duration }>5 \text { days }\end{array}$ & $\begin{array}{c}\text { Increase in mortality, } \mathrm{T} \text { as predictor: } \\
\text { Arkhangelsk, IHD RR }=1.16 \%(95 \% \\
\text { CI: } 1.037-1.31), \mathrm{CVD}=1.30 \%(95 \% \mathrm{CI}: \\
1.15-1.46) \\
\text { Murmansk IHD }=1.24 \%(95 \% \mathrm{CI}: \\
1.07-1.42), \mathrm{CVD}=1.10 \%(95 \% \mathrm{CI}: \\
0.94-1.29) \\
\text { Yakutsk IHD }=1.26 \%(95 \% \mathrm{CI}: \\
1.03-1.53), \mathrm{CVD}=1.36 \%(95 \% \mathrm{CI}: \\
1.05-1.76)\end{array}$ \\
\hline Revich et al. [101] & St-Petersburg & 1999-2016 & Daily T, WCI & $\begin{array}{l}\text { CW: } \mathrm{T}(\mathrm{WCI})<3 \text { rd } \\
\text { percentile of the year-round } \\
\text { distribution during period } \\
\text { from } 1961 \text { to } 2017, \\
\text { duration }>5 \text { days }\end{array}$ & $\begin{array}{c}\mathrm{T} \text { as predictor: } \mathrm{RD}(\geq 65) \mathrm{RR}=1.19 \% \\
(95 \% \mathrm{CI}: 1.01-1.40)\end{array}$ \\
\hline $\begin{array}{l}\text { Shaposhnikov, } \\
\text { Revich [107] }\end{array}$ & $\begin{array}{l}\text { Northern cities } \\
\text { Arkhangelsk, } \\
\text { Magadan, } \\
\text { Murmansk, } \\
\text { Yakutsk }\end{array}$ & 1999-2007 & Daily T & $\begin{array}{l}\text { CW: } \mathrm{T}(\mathrm{WCI})<3 \text { rd } \\
\text { percentile of the year-round } \\
\text { distribution during study } \\
\text { period, duration }>5 \text { days }\end{array}$ & $\begin{array}{c}\text { Arkhangelsk: IHD (30-64 years) } \\
\text { RR }=1.18,(\geq 65)=1.22 ; \text { CVD } \\
(30-64)=1.13,(\geq 65)=1.19 ; \text { RD } \\
\text { (30-64 years) }=1.31 ; \text { NA }(30-64)=1.12 \\
\text { NA }(\geq 65)=1.18 ; \text { Murmansk: IHD } \\
(30-64)=1.18 ; \text { Magadan: IHD } \\
(\geq 65)=1.39 ; \text { CVD }(\geq 65)=1.66 ; \\
\text { Yakutsk: IHD }(30-64)=1.38 \\
(\geq 65)=1.41 ; \text { CVD }(\geq 65)=1.69 ; \text { RD } \\
(\geq 65)=1.97, \text { NA }(\geq 65)=1.24\end{array}$ \\
\hline Shartova et al. [111] & Arkhangelsk & 1999-2016 & Daily T, UTCI & $\begin{array}{l}\text { CW: } \mathrm{T}(\mathrm{UTCI})<3 \text { rd } \\
\text { percentile of the year-round } \\
\text { distribution during study } \\
\text { period, duration }>5 \text { days }\end{array}$ & $\begin{array}{l}\text { Increase in mortality: mean daily T for } \\
\text { women }(30-64 \text { years old }) \text { CHD }=0.74 \text {, } \\
\text { RD }(\geq 65)=0.58 \text {; minimum daily } \\
\text { UTCI for men CV }(30-64)=3.67 \text {, RD } \\
\qquad(\geq 65)=0.87\end{array}$ \\
\hline
\end{tabular}

${ }^{1}$ AT-Apparent Temperature by Steadman, ${ }^{\circ} \mathrm{C}$ [183]; HUM-Temperature-Humidity Index, ${ }^{\circ} \mathrm{C}$ [182]; PET—Physiological Equivalent Temperature, ${ }^{\circ} \mathrm{C}$ [184]; T-air temperature, ${ }^{\circ} \mathrm{C}$; Tmax-maximum air temperature, ${ }^{\circ} \mathrm{C}$; UTCI-Universal Thermal Climate Index, ${ }^{\circ} \mathrm{C}[185]$; WCI-Wind-Chill Index, ${ }^{\circ} \mathrm{C}$ [181]. ${ }^{2} \mathrm{CW}$ - cold wave; HW-heat wave; $\mu$-arithmetic mean daily temperature for all days for the period 1961-1990, $\sigma$ —standard deviation of daily temperature distribution. ${ }^{3}$ AMI—acute myocardial infarction; ED—external cause disease; CHD—coronary heart disease; CVD—cardiovascular disease; IHD—ischemic heart disease; NA—all non-accidental causes; $\mathrm{RD}$-respiratory disease; $\mathrm{RR}$-relative risk. 
A few more important points should be added. It was shown that the response to wood smoke consisted of higher inflammatory and cytotoxic reactions than those caused by urban solid particles, suggesting the forest fire pollution could be more dangerous than urban pollution [195]. Although forest fires can occur only in certain regions, their smoke plumes can spread over long distances without borders [196]. More research is needed to assess the long-term health effects of forest fires; understanding such factors is vital to ensure that health services are prepared for these events [73].

Significant violations of the body functions during temperature waves lead to severe health losses, to decrease in the number of healthy years of life, which ultimately affects economic indicators $[87,88,94,190]$. All results from 16 research studies mentioned above are summarized in Table 2, where the papers are arranged alphabetically by the first author in the included studies. The following characteristics of studies involved in the review were extracted: study (year of publication); study area; study period - the period for which health data were estimated; extremely hot (cold) weather description, including definition of heat (cold) waves used in the study, as well as a referenced period, which in most cases was the same as the study period; results with outcome and associated lag time (Table 2).

\section{Concluding Comments}

The results of studies of the relationships between heat (cold) waves and health outcomes in Russian cities at the beginning of the 21st century are critically reviewed. A more significant increase in all-cause mortality is shown for heat waves than for cold waves in cities with a temperate continental climate, compared with cities in other climatic zones. In southern cities, the relative increase in natural mortality during cold waves is $10 \%$ per day, which is significantly less than during heat waves. Long waves demonstrate the greatest threat for the health.

Cardiovascular system diseases are the main causes of excess mortality during heat and cold waves. At high temperatures, excess mortality from coronary heart disease and strokes increased to the greatest extent in southern cities than in northern ones $[94,145]$. Thus, the assumption that residents of southern cities are adapted to high temperatures has not been confirmed.

\subsection{Combined Effects of Temperature Waves and COVID-19 on Human Health}

It is well documented that weather and climate act considerably on the transmission of infectious disease due to changes in transfer, host sensitivity and viability of the virus in the surroundings [197]. Recent studies show a link between weather variables such as air temperature, humidity, wind speed, precipitation and the transmission of COVID-19, with temperature being the most important predictor, and the highest incidence of COVID19 recorded in the temperature diapason of $0-17{ }^{\circ} \mathrm{C}$ [197]. Much less is known about associations with extreme temperature events. As the coronavirus disease (COVID-19) pandemic continues in the summer of 2021, the problem is to identify overlapping risk groups, which include elderly with pre-existing disease and medical staff due to the use of individual protective equipment; strategies should be proposed to mitigate the consequences of both the heat and viral threat [197-200]. Understanding the links between thermally extreme environments and human respiratory infections in different temperature regimes can reduce the turbulence and distribution of a new COVID-19 pandemic or any other in the future.

One more consideration is air pollution as a risk factor of development of coronavirus infection in cities. Suspended substances in the air can form clusters with coronavirus particles and thus spread to distances of up to $10 \mathrm{~m}$ from the source of infection, thereby contributing to infection. The importance of taking into account air pollution when modeling the spread of the COVID-19 pandemic is caused by the similarity of the mechanisms of influence of the coronavirus and the respiratory fraction of suspended substances on the human body - the immune response in both cases can be a cytokine storm, as a result of which a severe form of a systemic inflammatory reaction is formed, leading to damage to 
the respiratory organs and other systems of the human body [201]. According to published model estimates, at least $6.6 \%$ of deaths from COVID-19 in Europe, and up to deaths 11\% in China, where pollution levels are significantly high, are due to atmospheric air pollution. In Russian cities with an increased level of environmental pollution, air quality may affect the spread of COVID-19 [201].

\subsection{Urban Heat Island Effect}

It is well-known that urban temperatures increase dramatically because of climate variability. The main reasons could be expressed as follows: artificial heat from urban transport system, other industrial activities due to the consumption of fossil fuels; heat flow from buildings; replacement of natural land cover by artificial with different thermal properties; population growth and population ageing, which is manifested in Urban Heat Island effect $[63,76,85,127,128,140,157,158,202]$. Whilst excessive urban heat from UHI aggravates the effect of extremely high temperatures on human health, cold is estimated to play an equally important role $[157,158]$. During cold waves, living in cold, damp or moldy buildings without proper air filtration is considered a high-risk factor for exacerbation of respiratory disease [203]. Adequate heating and ventilation systems for wintertime, as well as sufficient air conditioning for summer, may be the most crucial mitigation solution for improving the indoor environment and preventing body cooling and (or) overheating [44,203,204].

Mortality is the most important indicator in assessing vulnerability to extreme climatic events [124,127]. Since a negative correlation has been found between the level of urbanization and heat vulnerability, it offers substantial data for future policy development in the field of UHI effect mitigation and adaptation to climate change [123,127]. Special regional-specific measures and emphasis should be reasonably adjusted together with the urbanization process according to the characteristics and key factors of local heat vulnerability [123,127]. Planning for the development of urban areas is essential for successful adaptation to local manifestations of climate change, since a significant part of climate risks falls on urban areas $[53,62]$. Natural solutions such as blue or green strategies should be embedded within the urban structures to help reduce thermal stress $[62,205,206]$. The continuing migration of the rural population and urban residents from small towns to larger cities, especially in the southern regions, leads to an increase in population risks from heat waves.

\subsection{Mitigation Policy and Prevention Plans}

To adequately protect the health of the population from the effects of heat waves, it is necessary to know about the air temperature thresholds, when exceeding which a set of preventive measures should be carried out. While most of the dangerous climatic events cannot be completely avoided, health impacts can potentially be prevented through early warning systems and public health preparedness and response measures, establishing climate-resilient health systems and other management structures [155,207-210]. In the framework of evidence-based medicine, such a temperature threshold can be determined using a numerical health risk criterion based on ecological and epidemiological studies and the use of percentiles of the long-term distribution of mean daily temperature in summer. The justification of temperature thresholds from the position of health risk is a step forward compared to the purely "synoptic" approach of the World Meteorological Organization (WMO) and the Russian Federal Hydrometeorological Service to definition of heat wave as an extreme phenomenon. Our research shows that the choice of a heat-wave threshold at the level of 97th percentile is reasonable for practical purposes of mitigating the effect of temperature extremes.

Naturally, part of damage to health from thermal stress can be prevented by timely informing the population about the onset of heat and carrying out certain preventive measures. In different countries, public notification systems are built according to different principles. A three-stage warning system operates in Philadelphia, and various preventive 
measures are provided, depending on the weather forecast. After the severe mortality impacts of the extreme summer heat 2003 in Europe, in 2008, Germany took up the National Adaptation Strategy on Climate Change to tackle and manage the impacts of weather extremes, for example to protect people's health against heat [85]. The German Meteorological service (DWD) monitors the heat load daily from May to September, publishing warnings about the onset of extreme heat [154].

In Russia, millions of people live in megacities and other large cities, and are exposed to heat waves, but only two adaptation action plans have been developed-in Arkhangelsk as part of a project of the WHO European Office, and in Moscow [209]. After the heat wave of 2010, specialists of the National Medical Center of Cardiology of the Ministry of Health of the Russian Federation, developed a system of comprehensive prevention of complications of cardiovascular diseases, based on a series of clinical and epidemiological studies $[42,115]$. Prevention of negative health effect is necessary, despite the duration of the expected period with hot weather: it was shown that even short heat waves lasting 3-5 days, without which almost no Moscow summer can do, lead to an increase in the number of complications in patients with cardiovascular diseases by four and a half times [114]. The Hydrometeorological Center of Russia, together with the Lomonosov Moscow State University and several European Meteorological organizations, are developing a new system of meso-scale numerical weather modeling, and therefore it will be possible to prepare in advance for temperature waves that are dangerous to public health [209].

At the same time, during the cold waves, preventive measures at the individual and population levels should be taken to guarantee the safety of outdoor activity $[159,163,164]$. To work in extremely cold weather conditions, it is necessary to clearly plan and organize the traffic depending on the perceived outdoor temperature; compliance with the work and rest regime, including sufficient indoor heating to normalize the thermal state of the body; providing employees with high-calorific food, proper clothing and periodic change of clothing items (shoes, socks, and gloves). If it is impossible to change the conditions, the harm to health from the effects of harsh frosty weather should be minimized to reduce the potential risk of disability and exacerbation of chronic diseases. Cold weather plans, which are critical for urban planning and design policies, should aim to reduce the health consequences, both mortality and morbidity or disability, in a cost-effective way [59,211].

\section{Conclusions}

In Russia over the last 20 years of the 21st century, both mean temperature and its high and low threshold percentiles have increased significantly compared to the previous period. At the same time, it can be expected that during global warming, excessive mortality due to an increase in the number of hot days can be partially compensated by a decrease in the number of cold waves. The results of Russian studies on the assessment of the impact of heat and cold waves on human health of population in megacities (Moscow, Saint Petersburg) and other large cities located in various climatic zones - in the Arctic, in Siberia and the southern areas, in an ultra-continental and monsoon climate, are systematized. It is shown that heat waves in cities with a temperate continental climate lead to a more significant increase in all-cause mortality than cold waves, compared with cities in other climatic zones. At the same time, in the northern cities, in contrast to the southern regions and central Siberia, the influence of cold waves is more pronounced on mortality than heat waves. In general, cold waves cause much greater risks to public health in the northern cities than in the southern ones.

To mitigate the impact of temperature extremes on human health and adequately protect population from the effects of temperature waves, it is necessary to know about the air temperature thresholds, which can be determined using a numerical health risk criterion based on ecological and epidemiological studies and the use of percentiles of the long-term distribution of mean daily temperature in summer and winter. The justification of temperature thresholds from the standpoint of health risk is a step forward compared to the purely "synoptic" approach with definition of heat (cold) wave as an extreme phenomenon by 
World Meteorological Organization and the Russian Federal Hydrometeorological Service. The results of our research show that in summer, for practical purposes of protecting the population, the choice of a threshold at the level of $97 \%$ percentile is justified.

Given the fact that the response of human health to temperature waves in various regions is different, it is important the planned and adopted countermeasures should be adequate for various climatic and/or social conditions.

Author Contributions: Conceptualization, methodology, data curation, writing-original draft preparation, writing, review and editing, B.A.R. and E.A.G.; visualization, E.A.G. All authors have read and agreed to the published version of the manuscript.

Funding: This research was funded within the framework of the State Task of the IEF RAS No. 168.5 "Compilation and clarification of short, medium and long-term forecasts for the development of the social sector of the economy", and the State Task of ICARP FEB RAS No. 075-00702-21-00 PR.

Institutional Review Board Statement: Not applicable.

Informed Consent Statement: Not applicable.

Data Availability Statement: Not applicable.

Conflicts of Interest: The authors declare no conflict of interest.

\section{References}

1. AghaKouchak, A.; Chiang, F.; Huning, L.S.; Love, C.A.; Mallakpour, I.; Mazdiyasni, O.; Moftakhari, H.; Papalexiou, S.M.; Ragno, E.; Sadegh, M. Climate Extremes and Compound Hazards in a Warming World. Annu. Rev. Earth Planet. Sci. 2020, 48, 519-548. [CrossRef]

2. Baldwin, J.W.; Dessy, J.B.; Vecchi, G.A.; Oppenheimer, M. Temporally Compound Heat Wave Events and Global Warming: An Emerging Hazard. Earths Future 2019, 7, 411-427. [CrossRef]

3. Ciavarella, A.; Cotterill, D.; Stott, P.; Kew, S.; Philip, S.; van Oldenborgh, G.J.; Skålevåg, A.; Lorenz, P.; Robin, Y.; Otto, F.; et al. Prolonged Siberian heat of 2020 almost impossible without human influence. Clim. Chang. 2021, 166, 1-18. [CrossRef]

4. Clarke, B.J.; Otto, F.E.L.; Jones, R.G. Inventories of extreme weather events and impacts: Implications for loss and damage from and adaptation to climate extremes. Clim. Risk Manag. 2021, 32, 100285. [CrossRef]

5. Coumou, D.; Rahmstorf, S. A decade of weather extremes. Nat. Clim. Chang. 2012, 2, 491-496. [CrossRef]

6. Cutter, S.L. Compound, Cascading, or Complex Disasters: What's in a Name? Environ. Sci. Policy Sustain. Dev. 2018, 60, 16-25. [CrossRef]

7. Diffenbaugh, N.S.; Singh, D.; Mankin, J.S.; Horton, D.E.; Swain, D.L.; Touma, D.; Charland, A.; Liu, Y.; Haugen, M.; Tsiang, M.; et al. Quantifying the influence of global warming on unprecedented extreme climate events. Proc. Natl. Acad. Sci. USA 2017, 114, 4881-4886. [CrossRef] [PubMed]

8. Ebi, K.L.; Vanos, J.; Baldwin, J.W.; Bell, J.E.; Hondula, D.M.; Errett, N.A.; Hayes, K.; Reid, C.E.; Saha, S.; Spector, J.; et al. Extreme Weather and Climate Change: Population Health and Health System Implications. Annu. Rev. Public Health 2021, 42, $293-315$. [CrossRef]

9. Fischer, E.M.; Sippel, S.; Knutti, R. Increasing probability of record-shattering climate extremes. Nat. Clim. Chang. 2021, 11, 689-695. [CrossRef]

10. Gessner, C.; Fischer, E.M.; Beyerle, U.; Knutti, R. Very Rare Heat Extremes: Quantifying and Understanding Using Ensemble Reinitialization. J. Clim. 2021, 34, 6619-6634. [CrossRef]

11. Gruza, G.V.; Rankova, E.Y. Observed and Expected Climate Changes in Russia: Air Temperature; VNIIGMI-MCD; Federal State Institution: Obninsk, Russia, 2012; 194p. (In Russian)

12. Groisman, P.; Shugart, H.; Kicklighter, D.; Henebry, G.; Tchebakova, N.; Maksyutov, S.; Monier, E.; Gutman, G.; Gulev, S.; Qi, J.; et al. Northern Eurasia Future Initiative (NEFI): Facing the challenges and pathways of global change in the twenty-first century. Prog. Earth Planet. Sci. 2017, 4, 41. [CrossRef]

13. Hao, Z.; Singh, V.P.; Hao, F. Compound Extremes in Hydroclimatology: A Review. Water 2018, 10, 718. [CrossRef]

14. Hoag, H. Russian summer tops 'universal' heatwave index. Nature 2014, 16. [CrossRef]

15. Ionita, M.; Caldarescu, D.E.; Nagavciuc, V. Compound Hot and Dry Events in Europe: Variability and Large-Scale Drivers. Front. Clim. 2021, 3, 58. [CrossRef]

16. IPCC, Intergovernmental Panel on Climate Change. Sixth Assessment Report Fact Sheet. 2021. Available online: https: //www.ipcc.ch/site/assets/uploads/2021/06/Fact_sheet_AR6.pdf (accessed on 30 August 2021).

17. Kharuk, V.I.; Ponomarev, E.I.; Ivanova, G.A.; Dvinskaya, M.L.; Coogan, S.C.P.; Flannigan, M.D. Wildfires in the Siberian taiga. Ambio 2021, 50, 1953-1974. [CrossRef] [PubMed]

18. Kuznetsova, V.P. Analyzing extreme weather phenomena in northern regions in the context of modern climate change. IOP Conf. Ser. Earth Environ. Sci. 2020, 611, 012050. [CrossRef] 
19. La Sorte, F.A.; Johnston, A.; Ault, T.R. Global trends in the frequency and duration of temperature extremes. Clim. Chang. 2021, 166, 1-14. [CrossRef]

20. Lau, W.K.M.; Kim, K.-M. The 2010 Pakistan Flood and Russian Heat Wave: Teleconnection of Hydrometeorological Extremes. J. Hydrometeorol. 2012, 13, 392-403. [CrossRef]

21. Mokhov, I.I.; Semenov, V.A. Weather and Climate Anomalies In Russian Regions Related to Global Climate Change. Russ. Meteorol. Hydrol. 2016, 41, 84-92. [CrossRef]

22. Mukherjee, S.; Mishra, A.K. Increase in Compound Drought and Heatwaves in a Warming World. Geophys. Res. Lett. 2021, 48, e2020GL090617. [CrossRef]

23. Otto, F.E.L.; Massey, N.; van Oldenborgh, G.J.; Jones, R.G.; Allen, M.R. Reconciling two approaches to attribution of the 2010 Russian heat wave. Geophys. Res. Lett. 2012, 39, L04702. [CrossRef]

24. Patz, J.A. Climate Variability and Change: Food, Water, and Societal Impacts. In Climate Change and Global Public Health. Respiratory Medicine; Pinkerton, K.E., Rom, W.N., Eds.; Humana: Cham, Switzerland, 2021; pp. 311-338. [CrossRef]

25. Perevedentsev, Y.P.; Shumikhina, A.V.; Shantalinskii, K.M.; Guryanov, V.V. Hydrometeorological Hazards in the Volga Federal District. Russ. Meteorol. Hydrol. 2019, 44, 802-809. [CrossRef]

26. Perkins-Kirkpatrick, S.E.; Lewis, S.C. Increasing trends in regional heatwaves. Nat. Commun. 2020, 11, 1-8. [CrossRef] [PubMed]

27. Prodhomme, C.; Materia, S.; Ardilouze, C.; White, R.H.; Batté, L.; Guemas, V.; Fragkoulidis, G.; García-Serrano, J. Seasonal prediction of European summer heatwaves. Clim. Dyn. 2021, 1-18. [CrossRef]

28. Russo, S.; Sillmann, J.; Fischer, E.M. Top ten European heatwaves since 1950 and their occurrence in the coming decades. Environ. Res. Lett. 2015, 10, 124003. [CrossRef]

29. Schiermeier, Q. Droughts, heatwaves and floods: How to tell when climate change is to blame. Nature 2018, 560, 20-22. [CrossRef]

30. Sena, A.; Ebi, K. When Land Is Under Pressure Health Is Under Stress. Int. J. Environ. Res. Public Health 2020, 18, 136. [CrossRef]

31. Shukla, P.R.; Skea, J.; Calvo Buendia, E.; Masson-Delmotte, V.; Pörtner, H.O.; Roberts, D.C.; Zhai, P.; Slade, R.; Connors, S.; Van Diemen, R.; et al. IPCC, 2019: Climate Change and Land: An IPCC Special Report on Climate Change, Desertification, Land Degradation, Sustainable Land Management, Food Security, and Greenhouse Gas Fluxes in Terrestrial Ecosystems; IPCC: Geneva, Switzerland, 2019.

32. Shvidenko, A.Z.; Shchepashchenko, D.G.; Vaganov, E.A.; Sukhinin, A.I.; Maksyutov, S.S.; McCallum, I.; Lakyda, I.P. Impact of wildfire in Russia between 1998-2010 on ecosystems and the global carbon budget. Dokl. Earth Sci. 2011, 441, 1678-1682. [CrossRef]

33. Smith, E.T.; Sheridan, S. Projections of Cold Air Outbreaks. In CMIP6 Earth System Models; Research Square: Durham, NC, USA, 2021. [CrossRef]

34. Tedim, F.; Leone, V.; Amraoui, M.; Bouillon, C.; Coughlan, M.R.; Delogu, G.M.; Fernandes, P.M.; Ferreira, C.; McCaffrey, S.; McGee, T.K.; et al. Defining Extreme Wildfire Events: Difficulties, Challenges, and Impacts. Fire 2018, 1, 9. [CrossRef]

35. Trenberth, K.E.; Fasullo, J. Climate extremes and climate change: The Russian heat wave and other climate extremes of 2010. J. Geophys. Res. 2012, 117, D17103. [CrossRef]

36. Twardosz, R.; Kossowska-Cezak, U. Large-area thermal anomalies in Europe (1951-2018). Temporal and spatial patterns. Atmospheric Res. 2021, 251, 105434. [CrossRef]

37. Ummenhofer, C.C.; Meehl, G.A. Extreme weather and climate events with ecological relevance: A review. Philos. Trans. R. Soc. B Biol. Sci. 2017, 372, 20160135. [CrossRef]

38. Vinogradova, V.V. Thermal impact on the territory of Russia in the middle of the XXI century according to model data. Izv. Ross. Akad. Nauk. Ser. Geogr. 2020, 3, 404-413. (In Russian) [CrossRef]

39. Zhang, M.; Chen, Y.; Shen, Y.; Li, B. Tracking climate change in Central Asia through temperature and precipitation extremes. J. Geogr. Sci. 2019, 29, 3-28. [CrossRef]

40. Zhang, P.; Ren, G.; Xu, Y.; Wang, X.L.; Qin, Y.; Sun, X.; Ren, Y. Observed Changes in Extreme Temperature over the Global Land Based on a Newly Developed Station Daily Dataset. J. Clim. 2019, 32, 8489-8509. [CrossRef]

41. Zscheischler, J.; Martius, O.; Westra, S.; Bevacqua, E.; Raymond, C.; Horton, R.M.; Hurk, B.V.D.; AghaKouchak, A.; Jézéquel, A.; Mahecha, M.D.; et al. A typology of compound weather and climate events. Nat. Rev. Earth Environ. 2020, 1, 333-347. [CrossRef]

42. Ageev, F.T.; Smirnova, M.D.; Galaninsky, P.V. Assessment of the immediate and delayed impact of the abnormally hot summer of 2010 on the cardiovascular diseases in outpatient practice. Ther. Arch. 2012, 8, 45-51. (In Russian)

43. Ageev, F.T.; Smirnova, M.D.; Svirida, O.N.; Fofanova, T.V.; Vitsenya, M.V.; Blankova, Z.N.; Mikhailov, G.V.; Lankin, V.Z.; Konovalova, G.G.; Tikhaze, A.K.; et al. Impact of a cold wave on disease course, hemodynamics, carbohydrate metabolism, and blood rheological properties in cardiac patents. Ter. Arkhiv 2015, 87, 11-16. [CrossRef] [PubMed]

44. Analitis, A.; Michelozzi, P.; D’Ippoliti, D.; De'Donato, F.; Menne, B.; Matthies, F.; Atkinson, R.W.; Iñiguez, C.; Basagaña, X.; Schneider, A.; et al. Effects of Heat Waves on Mortality. Epidemiology 2014, 25, 15-22. [CrossRef]

45. Anderko, L.; Chalupka, S.; Du, M.; Hauptman, M. Climate changes reproductive and children's health: A review of risks, exposures, and impacts. Pediatr. Res. 2020, 87, 414-419. [CrossRef]

46. Baccini, M.; Kosatsky, T.; Biggeri, A. Impact of Summer Heat on Urban Population Mortality in Europe during the 1990s: An Evaluation of Years of Life Lost Adjusted for Harvesting. PLoS ONE 2013, 8, e69638. [CrossRef]

47. Barriopedro, D.; Fischer, E.M.; Luterbacher, J.; Trigo, R.M.; García-Herrera, R. The Hot Summer of 2010: Redrawing the Temperature Record Map of Europe. Science 2011, 332, 220-224. [CrossRef] 
48. Basarin, B.; Lukić, T.; Matzarakis, A. Quantification and assessment of heat and cold waves in Novi Sad, Northern Serbia. Int. J. Biometeorol. 2015, 60, 139-150. [CrossRef]

49. Boytsov, S.A.; Lukyanov, M.M.; Deev, A.D.; Klyashtorny, V.G.; Ivanenko, A.V.; Volkova, N.S.; Kuznetsov, A.S.; Skvortsov, A.S.; Solovyev, D.V. The influence of environmental factors on the mortality of the population of Moscow: The possibilities of risks and forecasting. Russ. J. Cardiol. 2016, 6, 34-40. (In Russian) [CrossRef]

50. Brázdil, R.; Chromá, K.; Dolák, L.; Řehoř, J.; Řezníčková, L.; Zahradníček, P.; Dobrovolný, P. Fatalities associated with the severe weather conditions in the Czech Republic, 2000-2019. Nat. Hazards Earth Syst. Sci. 2021, 21, 1355-1382. [CrossRef]

51. Brennenstuhl, H.; Will, M.; Ries, E.; Mechler, K.; Garbade, S.; Ries, M. Patterns of extreme temperature-related catastrophic events in Europe including the Russian Federation: A cross-sectional analysis of the Emergency Events Database. BMJ Open 2021, 11, e046359. [CrossRef]

52. Carder, M.; McNamee, R.; Beverland, I.; Elton, R.; Cohen, J.; Boyd, J.; Agius, R. The lagged effect of cold temperature and wind chill on cardiorespiratory mortality in Scotland. Occup. Environ. Med. 2005, 62, 702-710. [CrossRef] [PubMed]

53. Cheng, W.; Li, D.; Liu, Z.; Brown, R.D. Approaches for identifying heat-vulnerable populations and locations: A systematic review. Sci. Total. Environ. 2021, 799, 149417. [CrossRef]

54. Chereshnev, V.A.; Gamburtsev, A.G.; Sigachev, A.V. Dynamics of ambulance calls in Moscow (2006-2011). Space Time 2013, 2, 220-228. (In Russian)

55. Chernykh, D.A.; Taseiko, O.V. Assessment of the Risk Mortality from Thermal Waves in Krasnoyarsk City. Hum. Ecol. 2018, 2, 3-8. (In Russian) [CrossRef]

56. Christidis, N.; Mitchell, D.; Stott, P.A. Anthropogenic climate change and heat effects on health. Int. J. Climatol. 2019, 39, 4751-4768. [CrossRef]

57. Curtis, S.; Fair, A.; Wistow, J.; Val, D.V.; Oven, K. Impact of extreme weather events and climate change for health and social care systems. Environ. Health 2017, 16, 128. [CrossRef]

58. De Sario, M.; Katsouyanni, K.; Michelozzi, P. Climate change, extreme weather events, air pollution and respiratory health in Europe. Eur. Respir. J. 2013, 42, 826-843. [CrossRef]

59. Díaz, J.; Carmona, R.; Miron, I.; Ortiz, C.; Linares, C. Comparison of the effects of extreme temperatures on daily mortality in Madrid (Spain), by age group: The need for a cold wave prevention plan. Environ. Res. 2015, 143, 186-191. [CrossRef]

60. Dimitriadou, L.; Nastos, P.; Zerefos, C. Defining Heatwaves with Respect to Human Biometeorology. The Case of Attica Region, Greece. Atmosphere 2021, 12, 1100. [CrossRef]

61. Dole, R.; Hoerling, M.; Perlwitz, J.; Eischeid, J.; Pegion, P.; Zhang, T.; Quan, X.-W.; Xu, T.; Murray, D. Was there a basis for anticipating the 2010 Russian heat wave? Geophys. Res. Lett. 2011, 38, L06702. [CrossRef]

62. Dong, J.; Peng, J.; He, X.; Corcoran, J.; Qiu, S.; Wang, X. Heatwave-induced human health risk assessment in megacities based on heat stress-social vulnerability-human exposure framework. Landsc. Urban Plan. 2020, 203, 103907. [CrossRef]

63. Ebi, K.L.; Capon, A.; Berry, P.; Broderick, C.; de Dear, R.; Havenith, G.; Honda, Y.; Kovats, R.S.; Ma, W.; Malik, A.; et al. Hot weather and heat extremes: Health risks. Lancet 2021, 398, 698-708. [CrossRef]

64. Eckstein, D.; Künzel, V.; Schäfer, L. Global Climate Risk Index. Who Suffers Most from Extreme Weather Events? Weather-Related Loss Events in 2019 and 2000-2019; Germanwatch: Bonn, Germany, 2021.

65. Evstafeva, E.V.; Lapchenko, V.A.; Macarova, A.S.; Abibullaeva, N.K.; Evstafeva, I.A. Air Temperature and Ozone Concentration as Risk Factors for Life-Threatening Cardiovascular Conditions in Southern Russia. Hum. Ecol. 2020, 5, 50-56. [CrossRef]

66. Forzieri, G.; Cescatti, A.; e Silva, F.B.; Feyen, L. Increasing risk over time of weather-related hazards to the European population: A data-driven prognostic study. Lancet Planet. Health 2017, 1, e200-e208. [CrossRef]

67. Garganeeva, A.A.; Kuzheleva, E.A.; Gorbatenko, V.P.; Okrugin, S.A.; Kuzhevskaya, I.V. Specifics of development and course of acute coronary insufficiency during extreme heat weather conditions. Cardiovasc. Ther. Prev. 2017, 16, 52-56. [CrossRef]

68. Gasparrini, A.; Guo, Y.; Hashizume, M.; Lavigne, E.; Zanobetti, A.; Schwartz, J.; Tobías, A.; Tong, S.; Rocklöv, J.; Forsberg, B.; et al. Mortality risk attributable to high and low ambient temperature: A multicountry observational study. Lancet 2015, 386, 369-375. [CrossRef]

69. Grigorieva, E.A. Heat waves in Khabarovsk-Approaches to the definition. Reg. Probl. 2014, 17, 43-48. (In Russian)

70. Grigorieva, E.A. Heat waves in the South of the Far East and human health. Newsl. Public Health Habitat 2017, 2, 11-14. (In Russian)

71. Grigorieva, E. Cold waves: Approaches to definition and examples for Khabarovsk. Reg. Probl. 2019, 22, 24-37. [CrossRef]

72. Grigorieva, E.A. Heat and cold waves in the South of the Russian Far East in 2000-2017. IOP Conf. Ser. Earth Environ. Sci. 2020, 606, 012016. [CrossRef]

73. Grigorieva, E.; Lukyanets, A. Combined Effect of Heat Waves and Outdoor Air Pollution on Respiratory Health: Literature Review. Atmosphere 2021, 12, 790. [CrossRef]

74. Guo, Y.; Gasparrini, A.; Armstrong, B.G.; Tawatsupa, B.; Tobías, A.; Lavigne, E.; Coelho, M.D.S.Z.S.; Pan, X.; Kim, H.; Hashizume, M.; et al. Heat Wave and Mortality: A Multicountry, Multicommunity Study. Environ. Health Perspect. 2017, 125, 087006. [CrossRef]

75. Hajat, S.; Kovats, R.S.; Lachowycz, K. Heat-related and cold-related deaths in England and Wales: Who is at risk? Occup. Environ. Med. 2007, 64, 93-100. [CrossRef] [PubMed]

76. Javadinejad, S.; Dara, R.; Jafary, F. Health impacts of extreme events. Saf. Extreme Environ. 2020, 2, 171-181. [CrossRef] 
77. Kendrovski, V.; Baccini, M.; Martinez, G.S.; Wolf, T.; Paunovic, E.; Menne, B. Quantifying Projected Heat Mortality Impacts under 21st-Century Warming Conditions for Selected European Countries. Int. J. Environ. Res. Public Health 2017, 14, 729. [CrossRef]

78. Liu, J.C.; Pereira, G.; Uhl, S.A.; Bravo, M.A.; Bell, M.L. A systematic review of the physical health impacts from non-occupational exposure to wildfire smoke. Environ. Res. 2015, 136, 120-132. [CrossRef] [PubMed]

79. Ma, F.; Yuan, X. Impact of climate and population changes on the increasing exposure to summertime compound hot extremes. Sci. Total. Environ. 2021, 772, 145004. [CrossRef] [PubMed]

80. Ma, Y.; Zhou, J.; Yang, S.; Yu, Z.; Wang, F.; Zhou, J. Effects of extreme temperatures on hospital emergency room visits for respiratory diseases in Beijing, China. Environ. Sci. Pollut. Res. 2018, 26, 3055-3064. [CrossRef]

81. Margolis, H.G. Heat Waves and Rising Temperatures: Human Health Impacts and the Determinants of Vulnerability. In Climate Change and Global Public Health. Respiratory Medicine; Pinkerton, K.E., Rom, W.N., Eds.; Humana: Cham, Switzerland, 2021; pp. 123-161. [CrossRef]

82. McElroy, S.; Schwarz, L.; Green, H.; Corcos, I.; Guirguis, K.; Gershunov, A.; Benmarhnia, T. Defining heat waves and extreme heat events using sub-regional meteorological data to maximize benefits of early warning systems to population health. Sci. Total. Environ. 2020, 721, 137678. [CrossRef]

83. McGregor, G.R.; Bessemoulin, R.; Ebi, K.; Menne, B. Heatwaves and Health: Guidance on Warning-System Development; World Meteorological Organization and World Health Organization: Geneva, Switzerland, 2015; p. 1142. Available online: http: / / bit.ly/2NbDx4S (accessed on 20 August 2021).

84. Meierrieks, D. Weather shocks, climate change and human health. World Dev. 2021, 138, 105228. [CrossRef]

85. Mücke, H.-G.; Litvinovitch, J.M. Heat Extremes, Public Health Impacts, and Adaptation Policy in Germany. Int. J. Environ. Res. Public Health 2020, 17, 7862. [CrossRef]

86. Oppermann, E.; Kjellstrom, T.; Lemke, B.; Otto, M.; Lee, J.K.W. Establishing intensifying chronic exposure to extreme heat as a slow onset event with implications for health, wellbeing, productivity, society and economy. Curr. Opin. Environ. Sustain. 2021, 50, 225-235. [CrossRef]

87. Otrachshenko, V.; Popova, O.; Solomin, P. Misfortunes never come singly: Consecutive weather shocks and mortality in Russia. Econ. Hum. Biol. 2018, 31, 249-258. [CrossRef]

88. Otrachshenko, V.; Popova, O.; Tavares, J. Extreme Temperature and Extreme Violence: Evidence from Russia. Econ. Inq. 2021, 59, 243-262. [CrossRef]

89. Patz, J.A.; Thomson, M.C. Climate change and health: Moving from theory to practice. PLoS Med. 2018, 15, e1002628. [CrossRef]

90. Perkins, S.E.; Alexander, L. On the Measurement of Heat Waves. J. Clim. 2013, 26, 4500-4517. [CrossRef]

91. Peters, A.; Schneider, A. Cardiovascular risks of climate change. Nat. Rev. Cardiol. 2021, 18, 1-2. [CrossRef] [PubMed]

92. Qiu, H.; Tian, L.; Ho, K.-F.; Yu, I.T.S.; Thach, T.-Q.; Wong, C.-M. Who is more vulnerable to death from extremely cold temperatures? A case-only approach in Hong Kong with a temperate climate. Int. J. Biometeorol. 2016, 60, 711-717. [CrossRef]

93. Revich, B.A. Heat waves, atmospheric air quality and mortality in the European part of Russia in the summer of 2010: Results of a preliminary assessment. Hum. Ecol. 2011, 7, 3-9. (In Russian)

94. Revich, B.A. Climatic risks to the health of residents of megacities of different climatic zones. In A Man in a Megalopolis. Experience of Interdisciplinary Research; Revich, B.A., Kuznetsova, O.V., Eds.; LENAND: Moscow, Russia, 2018; pp. 340-375. (In Russian)

95. Revich, B.A.; Grigorieva, E.A. Health Risks to the Russian Population from Weather Extremes in the Beginning of the XXI Century. Part 1. Heat and Cold Waves. Issues Risk Anal. 2021, 18, 12-33. [CrossRef]

96. Revich, B.A.; Shaposhnikov, D.A.; Pershagen, Y. A new epidemiological model for assessing the impact of abnormal heat and polluted atmospheric air on the mortality of the population (on the example of Moscow in 2010). Prev. Med. 2015, 5, 5-19. (In Russian)

97. Revich, B.A.; Shaposhnikov, D.V.; Podolnaya, M.A.; Kharkova, T.L.; Kvasha, E.A. Heat waves in southern cities of the European part of Russia as a risk factor for premature mortality of the population. Stud. Russ. Econ. Dev. 2015, 2, 55-67. (In Russian)

98. Revich, B.; Shaposhnikov, D. Influence features of cold and heat waves to the population mortality-the city with sharply continental climate. Sib. Med Rev. 2017, 2, 84-90. [CrossRef]

99. Revich, B.A.; Shaposhnikov, D.A.; Anisimov, O.A.; Belolutskaya, M.A. Heat and cold waves in cities located in the Arctic and Subarctic zones as risk factors for increasing population mortality on the example of Arkhangelsk, Murmansk and Yakutsk. Hyg. Sanit. 2018, 9, 791-799. [CrossRef]

100. Revich, B.A.; Shaposhnikov, D.A.; Anisimov, O.A.; Belolutskaya, M.A. Impact of Temperature Waves on the Health of Residents in Cities of the Northwestern Region of Russia. Stud. Russ. Econ. Dev. 2019, 30, 327-333. [CrossRef]

101. Revich, B.A.; Shaposhnikov, D.A.; Shkolnik, I.M. Projections of temperature-dependent mortality In Russian subarctic under climate change scenarios: A longitudinal study across several climate zones. IOP Conf. Ser. Earth Environ. Sci. 2020, 606, 012050. [CrossRef]

102. Robinson, P.J. On the definition of a heat wave. J. Appl. Meteorol. 2001, 40, 762-775. [CrossRef]

103. Rom, W.N.; Pinkerton, K.E. Introduction: Consequences of Global Warming to Planetary and Human Health. In Climate Change and Global Public Health; Pinkerton, K.E., Rom, W.N., Eds.; Respiratory Medicine; Humana: Cham, Switzerland, 2021; pp. 1-33. [CrossRef]

104. Rorie, A.; Poole, J.A. The Role of Extreme Weather and Climate-Related Events on Asthma Outcomes. Immunol. Allergy Clin. North Am. 2021, 41, 73-84. [CrossRef] [PubMed] 
105. Ryti, N.; Guo, Y.; Jaakkola, J.J. Global Association of Cold Spells and Adverse Health Effects: A Systematic Review and Meta-Analysis. Environ. Health Perspect. 2016, 124, 12-22. [CrossRef] [PubMed]

106. Seltenrich, N. Between Extremes: Health Effects of Heat and Cold. Environ. Health Perspect. 2015, 123, A275-A280. [CrossRef] [PubMed]

107. Shaposhnikov, D.; Revich, B. Towards meta-analysis of impacts of heat and cold waves on mortality In Russian North. Urban Clim. 2016, 15, 16-24. [CrossRef]

108. Shaposhnikov, D.; Revich, B.; Bellander, T.; Bedada, G.B.; Bottai, M.; Kharkova, T.; Kvasha, E.; Lezina, E.; Lind, T.; Semutnikova, E.; et al. Mortality Related to Air Pollution with the Moscow Heat Wave and Wildfire of 2010. Epidemiology 2014, 25, 359-364. [CrossRef]

109. Shartova, N.; Shaposhnikov, D.; Konstantinov, P.; Revich, B. Cardiovascular mortality during heat waves in temperate climate: An association with bioclimatic indices. Int. J. Environ. Health Res. 2018, 28, 522-534. [CrossRef]

110. Shartova, N.V.; Shaposhnikov, D.A.; Konstantinov, P.I.; Revich, B.A. Bioclimatic approach to the assessment of population mortality during the heat wave on the example of the South of Russia. Bull. Mosc. Univ. Ser. 5 Geogr. 2018, 6, 47-55. (In Russian)

111. Shartova, N.V.; Shaposhnikov, D.A.; Konstantinov, P.I.; Revich, B.A. Universal Thermal Climate Index (UTCI) applied to determine thresholds for temperature-related mortality. Health Risk Anal. 2019, 3, 83-93. [CrossRef]

112. Sheridan, S.C.; Allen, M.J. Changes in the Frequency and Intensity of Extreme Temperature Events and Human Health Concerns. Curr. Clim. Chang. Rep. 2015, 1, 155-162. [CrossRef]

113. Smirnova, M.; Gorbunov, V.; Andreeva, G. The influence of seasonal meteorological factors on the morbidity and mortality of the population from cardiovascular and bronchopulmonary diseases. Prev. Med. 2012, 15, 76-86. (In Russian)

114. Smirnova, M.D.; Ageev, F.T.; Svirida, O.N.; Konovalova, G.G.; Tikhaze, A.K.; Lankin, V.Z. Influence of summer heat on the health status of patients with moderate and high risk of cardiovascular complications. Cardiovasc. Ther. Prev. 2013, 12, 56-61. [CrossRef]

115. Smirnova, M.D.; Fofanova, T.V.; Yarovaya, E.B.; Ageev, F.T. Prognostic factors of cardiovascular complications during the 2010 heat wave (cohort observational study). Cardiol. Bull. 2016, 1, 43-51. (In Russian)

116. Smith, E.T.; Sheridan, S.C. The influence of extreme cold events on mortality in the United States. Sci. Total. Environ. 2019, 647, 342-351. [CrossRef]

117. Song, J.; Pan, R.; Yi, W.; Wei, Q.; Qin, W.; Song, S.; Tang, C.; He, Y.; Liu, X.; Cheng, J.; et al. Ambient high temperature exposure and global disease burden during 1990-2019: An analysis of the Global Burden of Disease Study 2019. Sci. Total. Environ. 2021, 787, 147540. [CrossRef] [PubMed]

118. Tong, S.L.; Olsen, J.; Kinney, P.L. Climate Change and Temperature-related Mortality: Implications for Health-related Climate Policy. Biomed. Environ. Sci. 2021, 34, 379-386.

119. Toulemon, L.; Barbieri, M. The mortality impact of the August 2003 heat wave in France: Investigating the 'harvesting' effect and other long-term consequences. Popul. Stud. 2008, 62, 39-53. [CrossRef]

120. Vanos, J.K.; Baldwin, J.W.; Jay, O.; Ebi, K.L. Simplicity lacks robustness when projecting heat-health outcomes in a changing climate. Nat. Commun. 2020, 11, 6079. [CrossRef]

121. Vanos, J.; Moyce, S.; Lemke, B.; Kjellstrom, T. Extreme Heat Exposure and Occupational Health in a Changing Climate. In Extreme Events and Climate Change; Castillo, F., Wehner, M., Stone, D.A., Eds.; John Wiley \& Sons, Inc.: Hoboken, NJ, USA, 2021. [CrossRef]

122. Vicedo-Cabrera, A.M.; Scovronick, N.; Sera, F.; Royé, D.; Schneider, R.; Tobias, A.; Astrom, C.; Guo, Y.; Honda, Y.; Hondula, D.M.; et al. The burden of heat-related mortality attributable to recent human-induced climate change. Nat. Clim. Chang. 2021, 11, 492-500. [CrossRef]

123. Wang, Y.; Shi, L.; Zanobetti, A.; Schwartz, J.D. Estimating and projecting the effect of cold waves on mortality in 209 US cities. Environ. Int. 2016, 94, 141-149. [CrossRef] [PubMed]

124. Watts, N.; Amann, M.; Arnell, N.; Ayeb-Karlsson, S.; Beagley, J.; Belesova, K.; Boykoff, M.; Byass, P.; Cai, W.; Campbell-Lendrum, D.; et al. The 2020 report of The Lancet Countdown on health and climate change: Responding to converging crises. Lancet 2021, 397, 129-170. [CrossRef]

125. Weilnhammer, V.; Schmid, J.; Mittermeier, I.; Schreiber, F.; Jiang, L.; Pastuhovic, V.; Herr, C.; Heinze, S. Extreme weather events in europe and their health consequences-A systematic review. Int. J. Hyg. Environ. Health 2021, 233, 113688. [CrossRef]

126. Young, J.; Arthur, R.; Spruce, M.; Williams, H. Social Sensing of Heatwaves. Sensors 2021, 21, 3717. [CrossRef]

127. Zemtsov, S.P.; Shartova, N.V.; Konstantinov, P.I.; Varentsov, M.I.; Kidyaeva, V.M. Vulnerability of the population of Moscow districts to natural hazards. Vestn. Mosk. Univ. Ser. 5 Geogr. 2020, 4, 3-13. (In Russian)

128. Zemtsov, S.; Shartova, N.; Varentsov, M.; Konstantinov, P.; Kidyaeva, V.; Shchur, A.; Timonin, S.; Grischchenko, M. Intraurban social risk and mortality patterns during extreme heat events: A case study of Moscow, 2010-2017. Health Place 2020, 66, 102429. [CrossRef]

129. Berry, H.L.; Bowen, K.; Kjellstrom, T. Climate change and mental health: A causal pathways framework. Int. J. Public Health 2010, 55, 123-132. [CrossRef] [PubMed]

130. Doherty, T.J.; Clayton, S. The psychological impacts of global climate change. Am. Psychol. 2011, 66, 265-276. [CrossRef]

131. Ioannou, L.; Mantzios, K.; Tsoutsoubi, L.; Panagiotaki, Z.; Kapnia, A.; Ciuha, U.; Nybo, L.; Flouris, A.; Mekjavic, I. Effect of a Simulated Heat Wave on Physiological Strain and Labour Productivity. Int. J. Environ. Res. Public Health 2021, 18, 3011. [CrossRef] 
132. Liu, J.; Varghese, B.M.; Hansen, A.; Xiang, J.; Zhang, Y.; Dear, K.; Gourley, M.; Driscoll, T.; Morgan, G.; Capon, A.; et al. Is there an association between hot weather and poor mental health outcomes? A systematic review and meta-analysis. Environ. Int. 2021, 153, 106533. [CrossRef]

133. Page, L.A.; Hajat, S.; Kovats, R.S.; Howard, L.M. Temperature-related deaths in people with psychosis, dementia and substance misuse. Br. J. Psychiatry 2012, 200, 485-490. [CrossRef] [PubMed]

134. Thompson, R.; Hornigold, R.; Page, L.; Waite, T. Associations between high ambient temperatures and heat waves with mental health outcomes: A systematic review. Public Health 2018, 161, 171-191. [CrossRef] [PubMed]

135. Yoo, E.-H.; Eum, Y.; Roberts, J.E.; Gao, Q.; Chen, K. Association between extreme temperatures and emergency room visits related to mental disorders: A multi-region time-series study in New York, USA. Sci. Total. Environ. 2021, 792, 148246. [CrossRef] [PubMed]

136. Yoo, E.-H.; Eum, Y.; Gao, Q.; Chen, K. Effect of extreme temperatures on daily emergency room visits for mental disorders. Environ. Sci. Pollut. Res. 2021, 28, 39243-39256. [CrossRef] [PubMed]

137. Rameshshanker, V.; Wyngaarden, S.; Lau, L.L.; Dodd, W. Health system resilience to extreme weather events in Asia-Pacific: A scoping review. Clim. Dev. 2021, 1-15. [CrossRef]

138. Matsueda, M. Predictability of Euro-Russian blocking in summer of 2010. Geophys. Res. Lett. 2011, 38, L06801. [CrossRef]

139. Friedman, L.S.; Abasilim, C.; Fitts, R.; Wueste, M. Clinical outcomes of temperature related injuries treated in the hospital setting, 2011-2018. Environ. Res. 2020, 189, 109882. [CrossRef]

140. Sera, F.; Armstrong, B.; Tobias, A.; Cabrera, A.M.V.; Åström, C.; Bell, M.L.; Chen, B.-Y.; Coelho, M.D.S.Z.S.; Correa, P.M.; Cruz, J.C.; et al. How urban characteristics affect vulnerability to heat and cold: A multi-country analysis. Int. J. Epidemiol. 2019, 48, 1101-1112. [CrossRef]

141. Zheng, S.; Zhu, W.; Shi, Q.; Wang, M.; Nie, Y.; Zhang, D.; Cheng, Z.; Yin, C.; Miao, Q.; Luo, Y.; et al. Effects of cold and hot temperature on metabolic indicators in adults from a prospective cohort study. Sci. Total. Environ. 2021, 772, 145046. [CrossRef]

142. Bedritsky, A.I. (Ed.) Russian Hydrometeorological Encyclopedia; Letnii Sad SPB: Moscow, Russia, 2008; Volume 1, 336p. (In Russian)

143. Kleshchenko, L.K. Heat and cold waves on the territory of Russia. Trudy GU VNIIGMI MTsD 2010, 175, 76-79. (In Russian)

144. Vinogradova, V.V. Winter cold waves on the territory of Russia since the second half of the twentieth century. Izv. Ross. Akad. Nauk. Ser. Geogr. 2018, 3, 37-46. (In Russian) [CrossRef]

145. Shaposhnikov, D.A.; Revich, B.A. On some approaches to calculating the health risks of temperature waves. Health Risk Anal. 2018, 1, 22-31. [CrossRef]

146. Roshydromet. RD 52.88699-2008. Regulation on the Procedure of Actions of Institutions and Organizations in the Event of a Threat of Dangerous Natural Processes; Roshydromet: Moscow, Russia, 2008. (In Russian)

147. Radinović, D.; Ćurić, M. Criteria for heat and cold wave duration indexes. Theor. Appl. Climatol. 2011, 107, 505-510. [CrossRef]

148. Rocklov, J.; Barnett, A.G.; Woodward, A. On the estimation of heat-intensity and heat-duration effects in time series models of temperature-related mortality in Stockholm, Sweden. Environ. Health 2012, 11, 23. [CrossRef] [PubMed]

149. De Freitas, C.R.; Grigorieva, E.A. The impact of acclimatization on thermophysiological strain for contrasting regional climates. Int. J. Biometeorol. 2014, 58, 2129-2137. [CrossRef] [PubMed]

150. De Freitas, C.R.; Grigorieva, E.A. Role of Acclimatization in Weather-Related Human Mortality During the Transition Seasons of Autumn and Spring in a Thermally Extreme Mid-Latitude Continental Climate. Int. J. Environ. Res. Public Health 2015, 12, 14974-14987. [CrossRef] [PubMed]

151. Fatima, S.H.; Rothmore, P.; Giles, L.C.; Varghese, B.M.; Bi, P. Extreme heat and occupational injuries in different climate zones: A systematic review and meta-analysis of epidemiological evidence. Environ. Int. 2021, 148, 106384. [CrossRef]

152. Foster, J.; Hodder, S.G.; Lloyd, A.B.; Havenith, G. Individual Responses to Heat Stress: Implications for Hyperthermia and Physical Work Capacity. Front. Physiol. 2020, 11, 541483. [CrossRef]

153. Jay, O.; Capon, A.; Berry, P.; Broderick, C.; de Dear, R.; Havenith, G.; Honda, Y.; Kovats, R.S.; Ma, W.; Malik, A.; et al. Reducing the health effects of hot weather and heat extremes: From personal cooling strategies to green cities. Lancet 2021, 398, 709-724. [CrossRef]

154. Mücke, H.-G.; Matzarakis, A. Climate Change and Health. Tips on Coping with Hot Weather and Heat Waves; Umweltbundesamt: Vienna, Austria, 2020; 20p. Available online: https:/ /www.umweltbundesamt.de/en/publikationen/climate-change-health-tipson-coping-hot-weather (accessed on 20 August 2021).

155. Taylor, N.A.S.; Notley, S.R.; Lindinger, M.I. Heat adaptation in humans: Extrapolating from basic to applied science. Eur. J. Appl. Physiol. 2021, 121, 1237-1238. [CrossRef]

156. Zafeiratou, S.; Samoli, E.; Dimakopoulou, K.; Rodopoulou, S.; Analitis, A.; Gasparrini, A.; Stafoggia, M.; Donato, F.D.; Rao, S.; Monteiro, A.; et al. A systematic review on the association between total and cardiopulmonary mortality/morbidity or cardiovascular risk factors with long-term exposure to increased or decreased ambient temperature. Sci. Total. Environ. 2021, 772, 145383. [CrossRef]

157. Marselle, M.R.; Hartig, T.; Cox, D.T.; de Bell, S.; Knapp, S.; Lindley, S.; Triguero-Mas, M.; Böhning-Gaese, K.; Braubach, M.; Cook, P.A.; et al. Pathways linking biodiversity to human health: A conceptual framework. Environ. Int. 2021, 150, 106420. [CrossRef]

158. Wang, Q.; Zhang, Y.; Ban, J.; Zhu, H.; Xu, H.; Li, T. The relationship between population heat vulnerability and urbanization levels: A county-level modeling study across China. Environ. Int. 2021, 156, 106742. [CrossRef]

159. Bocharov, M.I. Physiological Problems of Protection From Cold; SSU: Syktyvkar, Russia, 2004; 40p. (In Russian) 
160. Coccarelli, A.; Hasan, H.M.; Carson, J.; Parthimos, D.; Nithiarasu, P. Influence of ageing on human body blood flow and heat transfer: A detailed computational modelling study. Int. J. Numer. Methods Biomed. Eng. 2018, 34, e3120. [CrossRef] [PubMed]

161. Grishin, O.V.; Ustyuzhaninova, N.V. Breath in the North. Function. Structure. Reserves. Pathology; Artavenyu: Novosibirsk, Russia, 2006; 253p. (In Russian)

162. Kozyreva, T.V. Adaptation to cold of homeothermic organism: Changes in afferent and efferent links of the thermoregulatory system. J. Exp. Integr. Med. 2013, 3, 255-265. [CrossRef]

163. Nagornev, S.N.; Khudov, V.V.; Bobrovnitsky, I.P. Epidemiology of non-communicable diseases associated with adverse environmental impact and human activity in the Arctic. Russ. J. Restor. Med. 2019, 4, 3-37. (In Russian)

164. Rakhmanov, R.S.; Kolesov, S.A.; Alikberov, M.K.; Potekhina, N.N.; Belousko, N.I.; Tarasov, A.V.; Nepryakhin, D.V.; Zhargalov, S.I. On the issue of health risk under the influence of weather and climatic conditions in the cold period of the year for workers. Health Risk Anal. 2018, 2, 70-77. [CrossRef]

165. Wu, J.; Hu, Z.; Han, Z.; Gu, Y.; Yang, L.; Sun, B. Human physiological responses of exposure to extremely cold environments. J. Therm. Biol. 2021, 98, 102933. [CrossRef]

166. Kuzmin, S.B. Natural disasters in the Russian Federation. Issues Risk Anal. 2019, 16, 10-35. [CrossRef]

167. Zolotokrylin, A.N.; Vinogradova, V.V.; Glezer, O.B. (Eds.) Natural and Climatic Conditions and Sociogeographical Space of Russia; Institute of Geography RAS: Moscow, Russia, 2018; 154p. (In Russian)

168. The Global Risks Report 2020, 15th Edition. Available online: http://www3.weforum.org/docs/WEF\%20Global\%20Risk\%20 Report\%202020.pdf (accessed on 20 August 2021).

169. Roshydromet. Report on the Peculiarities of the Climate on the Territory of the Russian Federation for 2018; Roshydromet: Moscow, Russia, 2019; 79p.

170. Roshydromet. The Second Assessment Report of Roshydromet on Climate Change and Its Consequences on the Territory of the Russian Federation; Roshydromet: Moscow, Russia, 2014. (In Russian)

171. Overland, J.E.; Wang, M. The 2020 Siberian heat wave. Int. J. Climatol. 2021, 41 (Suppl. 1), E2341-E2346. [CrossRef]

172. COPERNICUS Wildfires. 2020. Available online: https:/ / atmosphere.copernicus.eu/another-active-year-arctic-wildfires (accessed on 20 August 2021).

173. Grishkin, D. Russia's Record-Breaking Heatwave to Continue into July-Weather Service. Moscow Times, 24 June 2021. Available online: https: / / www.themoscowtimes.com/2021/06/24/russias-record-breaking-heatwave-to-continue-into-july-weatherservice-a74319(accessed on 20 August 2021).

174. Hayes, K. Wildfire smoke Reaches North Pole for 1st Time in Recorded History. FOX TV Digital Team, 13 August 2021. Available online: https: / / www.fox35orlando.com/news / wildfire-smoke-reaches-north-pole-for-1st-time-in-recorded-history(accessed on 31 August 2021).

175. Titkova, T.B.; Cherenkova, E.A.; Semenov, V.A. Regional features of changes in winter extreme temperatures and precipitation in Russia in 1970-2015. Ice Snow 2018, 58, 486-497. [CrossRef]

176. Bardin, M.Y.; Platova, T.V. Changes in seasonal indicators of air temperature extremes in Moscow and the central regions of the European part of Russia. Meteorol. Hydrol. 2020, 7, 20-35. (In Russian)

177. Shaposhnikov, D.A.; Revich, B.A.; Shkolnik, I.M. Scenario estimates of climate warming and mortality In Russian Arctic cities in the XXI century. Health Risk Anal. 2019, 4, 37-49. [CrossRef]

178. Federal Center for Hygiene and Epidemiology of Rospotrebnadzor. Assessment of the Risk and Damage from Climate Change Affecting the Increase in Morbidity and Mortality in High-Risk Populations: Methodological Recommendations MR 2.1.10.0057-12; Federal Center for Hygiene and Epidemiology of Rospotrebnadzor: Moscow, Russia, 2012; 48p. (In Russian)

179. De Freitas, C.R.; Grigorieva, E.A. A comprehensive catalogue and classification of human thermal climate indices. Int. J. Biometeorol. 2015, 59, 109-120. [CrossRef] [PubMed]

180. De Freitas, C.R.; Grigorieva, E.A. A comparison and appraisal of a comprehensive range of human thermal climate indices. Int. J. Biometeorol. 2017, 61, 487-512. [CrossRef]

181. Osczevski, R.J. The Basis of Wind Chill. Arctic 1995, 48, 372-382. [CrossRef]

182. Masterson, J.; Richardson, F.A. Humidex, a Method of Quantifying Human Discomfort Due to Excessive Heat and Humidity; Environment Canada: Downsview, ON, Canada, 1979; 45p.

183. Steadman, R.G. A universal scale of apparent temperature. J. Clim. Appl. Meteorol. 1984, 23, 1674-1687. [CrossRef]

184. Matzarakis, A.; Mayer, H.; Iziomon, M. Applications of a universal thermal index: Physiological equivalent temperature. Int. J. Biometeorol. 1999, 43, 76-84. [CrossRef] [PubMed]

185. Broede, P.; Fiala, D.; Blazejczyk, K.; Holmér, I.; Jendritzky, G.; Kampmann, B.; Tinz, B.; Havenith, G. Deriving the operational procedure for the Universal Thermal Climate Index (UTCI). Int. J. Biometeorol. 2012, 56, 481-494. [CrossRef]

186. Peel, M.C.; Finlayson, B.L.; McMahon, T.A. Updated world map of the Köppen-Geiger climate classification. Hydrol. Earth Syst. Sci. 2007, 11, 1633-1644. [CrossRef]

187. Sedov, V.E. On climate fluctuations and climate trends in modern Moscow. Meteorol. Hydrol. 2012, 8, 47-58. (In Russian) [CrossRef]

188. Isaev, A.A. Ecological Climatology: Monograph; Nauch. Mir: Moscow, Russia, 2003; 470p. (In Russian)

189. Kislov, A.V.; Konstantinov, P.I. Detailed spatial modeling of the temperature of the Moscow megapolis. Meteorol. Hydrol. 2011, 5, 25-32. (In Russian)

190. Porfiriev, B.N. Economic assessment of human losses as a result of emergency situations. Econ. Iss. 2013, 1, 46-68. (In Russian) 
191. Climate Strategy of St. Petersburg. Project. 2016. Available online: http://www.gov.spb.ru/static/writable/ckeditor/01_klim_ str_roject.doc (accessed on 20 August 2021).

192. Grigorieva, E.A.; Khristoforova, N.K. Climate and Human Health at the Russian Far East. Ekol. Cheloveka 2019, 5, 4-10. [CrossRef]

193. Gilbert, N. Russia Counts Environmental Cost of Wildfires. Nat. News, 12 August 2010. Available online: https:/ /www.nature. com/articles/news.2010.404 (accessed on 20 August 2021).

194. Konovalov, I.B.; Beekmann, M.; Kuznetsova, I.N.; Yurova, A.; Zvyagintsev, A.M. Atmospheric impacts of the 2010 Russian wildfires: Integrating modelling and measurements of an extreme air pollution episode in the Moscow region. Atmospheric Chem. Phys. Discuss. 2011, 11, 10031-10056. [CrossRef]

195. Jalava, P.I.; Salonen, R.O.; Hälinen, A.I.; Penttinen, P.; Pennanen, A.; Sillanpää, M.; Sandell, E.; Hillamo, R.; Hirvonen, M.-R. In vitro inflammatory and cytotoxic effects of size-segregated particulate samples collected during long-range transport of wildfire smoke to Helsinki. Toxicol. Appl. Pharmacol. 2006, 215, 341-353. [CrossRef]

196. Finlay, S.E.; Moffat, A.; Gazzard, R.; Baker, D.; Murray, V. Health Impacts of Wildfires. PLoS Curr. 2012, 4, e4f959951cce2c. [CrossRef]

197. McClymont, H.; Hu, W. Weather Variability and COVID-19 Transmission: A Review of Recent Research. Int. J. Environ. Res. Public Health 2021, 18, 396. [CrossRef]

198. Bose-O’Reilly, S.; Daanen, H.; Deering, K.; Gerrett, N.; Huynen, M.M.T.E.; Lee, J.; Karrasch, S.; Matthies-Wiesler, F.; Mertes, H.; Schoierer, J.; et al. COVID-19 and heat waves: New challenges for healthcare systems. Environ. Res. 2021, 198, 111153. [CrossRef]

199. Martinez, G.; Linares, C.; De'Donato, F.; Diaz, J. Protect the vulnerable from extreme heat during the COVID-19 pandemic. Environ. Res. 2020, 187, 109684. [CrossRef]

200. Wilhelmi, O.V.; Howe, P.D.; Hayden, M.H.; O’Lenick, C.R. Compounding hazards and intersecting vulnerabilities: Experiences and responses to extreme heat during COVID-19. Environ. Res. Lett. 2021, 16, 084060. [CrossRef]

201. Revich, B.A.; Shaposhnikov, D.A. The COVID-19 Pandemic: New Knowledge on the Impact of Air Quality on the Spread of Coronavirus Infection in Cities. Stud. Russ. Econ. Dev. 2021, 32, 357-363. [CrossRef]

202. Oke, T.R. The energetic basis of the urban heat island. Q. J. R. Meteorol. Soc. 1982, 108, 1-24. [CrossRef]

203. Wimalasena, N.; Chang-Richards, A.; Wang, K.; Dirks, K. Housing Risk Factors Associated with Respiratory Disease: A Systematic Review. Int. J. Environ. Res. Public Health 2021, 18, 2815. [CrossRef]

204. Ehsan, S.; Abbas, F.; Ibrahim, M.; Ahmad, B.; Farooque, A. Thermal Discomfort Levels, Building Design Concepts, and Some Heat Mitigation Strategies in Low-Income Communities of a South Asian City. Int. J. Environ. Res. Public Health 2021, 18, 2535. [CrossRef]

205. Grigorieva, E. Bioclimate and urban design for sustainable development. In Water Management and Water Protection, Soil Consumption, Natural Capital Defense and Urban Growth; Proceedings of the Lugano HLRT Symposium 2019 by Water Academy SRD; Water Academy SRD: Lugano, Switzerland, 2020; pp. 99-107.

206. Ermolaeva, P.; Ermolaeva, Y.; Basheva, O.; Kuznetsova, I.; Korunova, V. The Russian Urban Sustainability Puzzle: How Can Russian Cities Be Green? (Emerald Points); Emerald Group Publishing Ltd.: Bingley, UK, 2021. [CrossRef]

207. Casanueva, A.; Burgstall, A.; Kotlarski, S.; Messeri, A.; Morabito, M.; Flouris, A.D.; Nybo, L.; Spirig, C.; Schwierz, C. Overview of Existing Heat-Health Warning Systems in Europe. Int. J. Environ. Res. Public Health 2019, 16, 2657. [CrossRef]

208. Pascal, M.; Laaidi, K.; Ledrans, M.; Baffert, E.; Caserio-Schönemann, C.; Le Tertre, A.; Manach, J.; Medina, S.; Rudant, J.; Empereur-Bissonnet, P. France's heat health watch warning system. Int. J. Biometeorol. 2005, 50, 144-153. [CrossRef]

209. Rivin, G.S.; Rozinkina, I.A.; Vil'fand, R.M.; Kiktev, D.B.; Tudrii, K.O.; Blinov, D.V.; Artamonov, A.Y. Development of the Highresolution Operational System for Numerical Prediction of Weather and Severe Weather Events for the Moscow Region. Russ. Meteorol. Hydrol. 2020, 45, 455-465. [CrossRef]

210. Toloo, G.; Fitzgerald, G.; Aitken, P.; Verrall, K.; Tong, S. Evaluating the effectiveness of heat warning systems: Systematic review of epidemiological evidence. Int. J. Public Health 2013, 58, 667-681. [CrossRef] [PubMed]

211. Chalabi, Z.; Hajat, S.; Wilkinson, P.; Erens, B.; Jones, L.; Mays, N. Evaluation of the cold weather plan for England: Modelling of cost-effectiveness. Public Health 2016, 137, 13-19. [CrossRef] [PubMed] 